\title{
Cell-Autonomous Regulation of Dendritic Spine Density by PirB
}

[Deorge S. Vidal," ${ }^{-}$Maja Djurisic,* ${ }^{\circledR}$ Kiana Brown, ${ }^{\circledR}$ Richard W. Sapp, and ${ }^{\circledR C}$ Carla J. Shatz

DOI:http://dx.doi.org/10.1523/ENEURO.0089-16.2016

Departments of Biology and Neurobiology, and Bio-X, James H. Clark Center, Stanford University, Stanford, California 94305

\section{Visual Abstract}

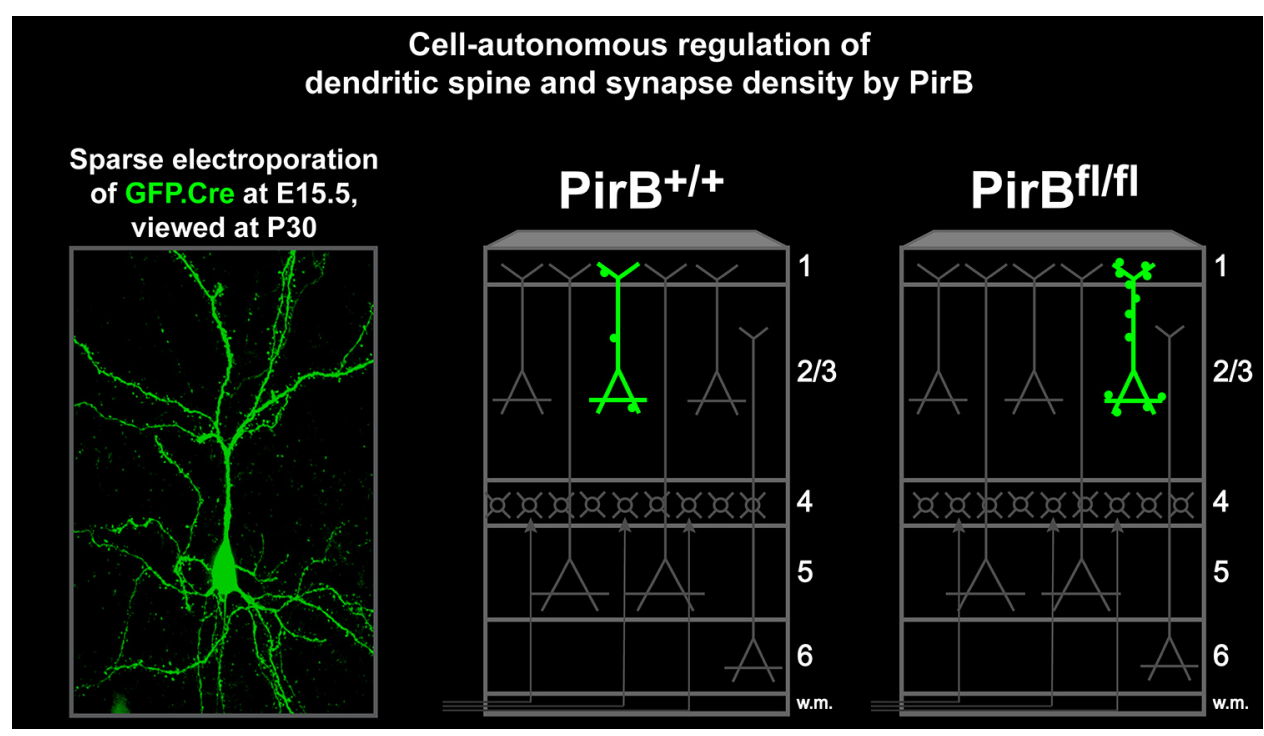

Synapse density on cortical pyramidal neurons is modulated by experience. This process is highest during developmental critical periods, when mechanisms of synaptic plasticity are fully engaged. In mouse visual cortex, the critical period for ocular dominance (OD) plasticity coincides with the developmental pruning of synapses. At this time, mice lacking paired Ig-like receptor B (PirB) have excess numbers of dendritic spines on L5 neurons; these spines persist and are thought to underlie the juvenile-like OD plasticity observed in adulthood. Here we examine whether PirB is required specifically in excitatory neurons to exert its effect on dendritic spine and synapse density during the critical period. In mice with a conditional allele of PirB (PirB $\left.{ }^{\mathrm{fl} / \mathrm{f}}\right)$, PirB was deleted only

\section{Significance Statement}

Dendritic spines, postsynaptic sites of excitatory synapses on pyramidal neurons, are regulated by experience and synaptic plasticity. Paired Ig-like receptor B (PirB) is known to restrict the extent of experience-dependent plasticity in visual cortex. Here we report that when PirB is removed in vivo from just a few isolated pyramidal neurons in layer $2 / 3$ of mouse visual cortex, spine density as well as the frequency of miniature synaptic currents (a measure of the density of functional synapses) are elevated selectively in the cells lacking PirB. These results suggest that PirB expression in individual neurons is sufficient to limit excitatory synaptic density on pyramidal neurons. This cell-intrinsic function of PirB could serve to ensure that pyramidal cells have sufficient structural reserve to encode new experiences. 
from L2/3 cortical pyramidal neurons in vivo by timed in utero electroporation of Cre recombinase. Sparse mosaic expression of Cre produced neurons lacking PirB in a sea of wild-type neurons and glia. These neurons had significantly elevated dendritic spine density, as well as increased frequency of miniature EPSCs, suggesting that they receive a greater number of synaptic inputs relative to $\mathrm{Cre}^{-}$neighbors. The effect of cell-specific PirB deletion on dendritic spine density was not accompanied by changes in dendritic branching complexity or axonal bouton density. Together, results imply a neuron-specific, cell-autonomous action of PirB on synaptic density in L2/3 pyramidal cells of visual cortex. Moreover, they are consistent with the idea that PirB functions normally to corepress spine density and synaptic plasticity, thereby maintaining headroom for cells to encode ongoing experience-dependent structural change throughout life.

Key words: cell-autonomous regulation; dendritic spine density; experience-dependent plasticity; PirB; structural plasticity; synapse pruning

\section{Introduction}

Cortical circuits are altered by experience throughout life and undergo extensive restructuring during early developmental critical periods. Underlying these experience-dependent circuit changes are cellular and molecular mechanisms of synaptic plasticity. Different learning and plasticity paradigms involving specific cortical regions result in a persistent increase in the density of dendritic spines, which are postsynaptic anatomical structures at excitatory synapses and represent sites of plasticity. This increase in dendritic spine density is thought to represent a structural trace of new learning. For example, mice trained on a forepaw reaching task show an increase in dendritic spine density on apical dendrites of L5 pyramidal cells in motor cortex (Xu et al., 2009b; Fu et al., 2012); changes are also seen in spine density on the dendrites of L2/3 pyramidal cells (Ma et al., 2016). When these newly formed spines are selectively disassembled, motor memories are erased (Hayashi-Takagi et al., 2015). In the binocular zone of mouse visual cortex, closure of one eye (monocular deprivation) generates an experiencedependent form of plasticity known as ocular dominance (OD) plasticity (Gordon and Stryker, 1996). This plasticity is accompanied by an enduring increase in spine density

Received April 19, 2016; accepted September 23, 2016; First published September 28, 2016.

The authors declare no competing financial interests.

Author contributions: G.S.V., M.D., and C.J.S. designed research; G.S.V., M.D., K.B., and R.W.S. performed research; G.S.V. and K.B. analyzed data; G.S.V., M.D. and C.J.S. wrote the paper.

This research was supported by National Eye Institute Grant R01-EY002858 and the G. Harold and Leila Y. Mathers Charitable Foundation (C.J.S.); a Regina Casper Stanford Graduate Fellowship and National Eye Institute Grant F31-EY-023518 (G.S.V.); and Stanford Bio-X Undergraduate Summer Research Fellowships (K.B. and R.W.S.).

${ }^{*}$ G.S.V. and M.D. contributed equally to this work

G.S. Vidal's present address: Department of Biology, James Madison University, MSC 7801, Harrisonburg, VA 22807.

Acknowledgments: We thank P. Kemper, C. Chechelski, and N. Sotelo-Kury for excellent mouse husbandry; Drs. B. Brott and K. Chew for helpful discussions; and Drs. K. Srinivasan, S.K. McConnell, H. Lee, and G. Panagiotakos for assistance with the in utero electroporation method.

Correspondence should be addressed to either Carla J. Shatz or George S. Vidal, James H. Clark Center, 318 Campus Drive W1.1, Stanford, CA 94305, E-mail: cshatz@stanford.edu or vidalgx@jmu.edu.

DOI:http://dx.doi.org/10.1523/ENEURO.0089-16.2016

Copyright () 2016 Vidal et al.

This is an open-access article distributed under the terms of the Creative Commons Attribution 4.0 International, which permits unrestricted use, distribution and reproduction in any medium provided that the original work is properly attributed. along the apical tufts of L5 pyramidal neurons (Hofer et al., 2009; Djurisic et al., 2013). As in motor cortex, this net increase in density is thought to provide a structural substrate that mediates a lower threshold for OD plasticity when the same eye is closed again later in life (Hofer et al., 2006, 2009).

In recent years, a list of molecules that appear to function normally as negative regulators of visual cortical plasticity has emerged, in the sense that gene knockout enhances OD plasticity following brief monocular deprivation. Blockade, removal, or genetic deletion of each of these molecules, including Nogo Receptor 1 (NgR1; McGee et al., 2005; Frantz et al., 2016), Lynx1 (Morishita et al., 2010; Bukhari et al., 2015), Death Receptor 6 (DR6; Marik et al., 2013), chondroitin sulfate proteoglycans (Pizzorusso et al., 2002), or paired Ig-like receptor B (PirB; Syken et al., 2006; Djurisic et al., 2013; Bochner et al., 2014), generates enhanced OD plasticity even in adult mice, well after normal closure of the critical period, and when significant OD plasticity cannot be elicited in wildtype mice. In addition, cell type-specific deletion of PirB from excitatory pyramidal neurons is sufficient to generate enhanced OD plasticity in adult visual cortex (Bochner et al. 2014). In mice with germline deletion ( $\mathrm{PirB}^{-1-}$ ), dendritic spine density is elevated not only during the critical period but also in adults, implying a developmental pruning defect (Djurisic et al., 2013). This elevation in spine density is thought to mediate the juvenile-like OD plasticity observed in adult visual cortex of these mice.

PirB is expressed in cortical pyramidal neurons. It was discovered in an in situ hybridization screen designed to identify receptors expressed in brain that bind $\mathrm{MHC}$ class I molecules, which are involved in activity-dependent plasticity (Syken et al. 2006; Adelson et al., 2012; Djurisic et al., 2013; Bochner et al., 2014; Adelson et al., 2016). The elevated spine density and enhanced OD plasticity in visual cortex of PirB ${ }^{-1-}$ mice could arise from a requirement for PirB function exclusively in neurons. Microglia are also intimately involved in synapse pruning (Schafer et al., 2012; Parkhurst et al., 2013), but PirB expression has not been detected in this cell type in vivo. Nevertheless, studies of germline PirB knock-out mice, in which both brain and immune systems are affected, cannot distinguish between these alternatives. Here we use timed in utero electroporation of Cre recombinase into developing $\mathrm{PirB}^{\mathrm{fl} / \mathrm{fl}}$ mouse ventricular zone (Saito and Nakatsuji, 2001) to investigate whether neuron-specific deletion of 
PirB is sufficient to explain changes in dendritic spine density seen in $\mathrm{PirB}^{-1-}$ mice (Djurisic et al., 2013) or following pharmacological blockade of PirB in adult wildtype visual cortex (Bochner et al. 2014). In addition, in utero electroporation permits sparse deletion of PirB in single L2/3 neurons embedded in a wild-type environment. This type of mosaic approach has been used in vivo to determine whether a particular gene function is cell autonomous (Hippenmeyer et al., 2010; Akbik et al., 2013; Lu et al., 2013). Here, sparse deletion of PirB in L2/3 pyramidal neurons demonstrates that neuronal PirB is required for the regulation of synaptic density, leading us to conclude that this function of PirB is cell intrinsic.

\section{Materials and Methods}

\section{Mice}

$\mathrm{PirB}^{\mathrm{fl} / f \mathrm{f}}, \mathrm{PirB}^{+/+}$, and $\mathrm{PirB}^{-/-}$mice were generated by Syken et al. (2006). Briefly, PirB ${ }^{\mathrm{fl} / \mathrm{fl}}$ mice were generated by electroporating a construct with loxP sites flanking exons 10-13 of PirB into the 129 J1 ES line derived from agouti 129S4/SvJae mice. Exons 10-13 of PirB code for the transmembrane domain of PirB, as well as part of the intracellular domain encompassing the signaling immunoreceptor tyrosine-based inhibitory motifs. Thus, Cremediated excision of exons 10-13 from the PirB gene in $\mathrm{PirB}^{\mathrm{fl} / \mathrm{fl}}$ mice results in a truncated protein that is unable to signal, as shown previously by anti-phosphotyrosine immunoprecipitation experiments (Syken et al., 2006). To generate mice with germ line deletion of PirB (i.e., PirB ${ }^{-\prime}$ - ), a deleter strain that targets Cre-recombinase expression to early mouse embryo via adenovirus Ella promoter (B6.FVB-TGN(Ella-cre)C5379Lmgd; The Jackson Laboratory) was crossed to $\mathrm{PirB}^{\mathrm{fl} / \mathrm{fl}}$ mice. Heterozygote sibling matings were then used to generate both control $\mathrm{PirB}^{+/+}$ line and a homozygous $\mathrm{PirB}^{-/-}$line (Syken et al., 2006). $\mathrm{PirB}^{\mathrm{fl} / f \mathrm{l}}, \mathrm{PirB}^{+/+}$, and $\mathrm{PirB}^{-/-}$mice were maintained as three separate lines on the same mixed genetic background (C57BL/6 $\times$ SV/129J). Previous studies have shown that the excision of PirB from PirB ${ }^{\mathrm{fl} / \mathrm{fl}}$ by Cre recombinase under control of the UbC promoter occurs within 1 week (Bochner et al., 2014), and is accompanied by a complete loss of PirB protein after $\sim 3$ weeks from the onset of Cre recombinase expression (Fig. 1; Bochner et al., 2014). Cre recombinase expression via the GFP.Cre construct under the phosphoglycerate kinase promoter used here for the electroporation experiments described below should be even more rapid and efficient (Qin et al., 2010).

All experiments were performed in accordance with the Guide for the Care and Use of Laboratory Animals of the National Institutes of Health and approved by the Stanford University Institutional Animal Care and Use Committee. Experimental methods are also in accordance with the policies of the Society for Neuroscience on the Use of Animals and Humans in Neuroscience Research. All mice were maintained in a pathogen-free environment.

\section{In utero electroporation}

Female mice were mated within the same line $\left(\mathrm{PirB}^{+/+}\right.$, $\mathrm{PirB}^{\mathrm{fl} / \mathrm{fl} l}$, or $\mathrm{PirB}^{-/-}$) and checked daily for vaginal plugs. The day that a plug was found was counted as embryonic day 0.5 (E0.5). In utero electroporation was performed at E15.5, when L2/3 cortical neurons are generated (Saito and Nakatsuji, 2001; Tabata and Nakajima, 2001; Saito, 2006; Chen et al., 2008). Pregnant mice were anesthetized using $1-2.5 \%$ isoflurane in $100 \% \mathrm{O}_{2}$. Using a sterile surgical technique, a midline incision was made to the abdominal wall to expose the uterine horns. Lateral ventricles of embryos were injected with either 1.0 or $1.5 \mu \mathrm{l}$ of 1.9-2.0 $\mu \mathrm{g} / \mu \mathrm{l}$ GFP.Cre in Tris-EDTA buffer (10 mm Tris$\mathrm{HCl}, \mathrm{pH}$ 8.0, and $1 \mathrm{~mm}$ ethylenediaminetetraacetic acid); injection of the lower $(1.0 \mu \mathrm{l})$ volume of DNA was critical to achieving sparse electroporations.

GFP.Cre is an expression construct in which GFP expression is driven by the ubiquitin $\mathrm{C}$ promoter, and Cre expression is driven separately by the phosphoglycerate kinase promoter (gift from Tyler Jacks, Koch Institute for Integrative Cancer Research at the Massachusetts Institute of Technology, Cambridge, Massachusetts; plasmid \#20781, Addgene; Andreu-Agullo et al., 2011; Scotto-Lomassese et al., 2011). Injections were achieved using micropipettes made from glass capillary tubes (TW100F-4, World Precision Instruments) pulled into a fine tip with a micropipette puller (P-97, Sutter Instruments). Tweezer-type circular electrodes (5 $\mathrm{mm}$ in diameter) were custom made by coiling 24 AWG platinum wire (PTP201, World Precision Instruments) and were used to deliver five $50 \mathrm{~ms}$ electric pulses at $45 \mathrm{~V}$ with $950 \mathrm{~ms}$ intervals, using a squarewave generator (ECM 830, BTX). The exposed uterus was kept moist with $0.9 \%$ saline at $37^{\circ} \mathrm{C}$. After each electroporation procedure, dams were given buprenorphine intraperitoneally $(0.1 \mathrm{mg} / \mathrm{kg}$; catalog \#2808, Tocris Bioscience), the abdominal wall was sutured shut, and the dam was allowed to recover in a cage kept at $\sim 37^{\circ} \mathrm{C}$. Pregnant dams were monitored postoperatively until after giving birth and able to nurse pups.

\section{Histology}

Mice received an overdose of sodium pentobarbital ( $>86 \mathrm{mg} / \mathrm{kg}$ ) and sodium phenytoin cocktail (Beuthanasia-D, Merck; $>11 \mathrm{mg} / \mathrm{kg}$, i.p.), and brain tissue was fixed via transcardial perfusion of ice-cold $0.1 \mathrm{~m}$ sodium PBS followed by ice-cold $4 \%(\mathrm{w} / \mathrm{v})$ paraformaldehyde in $0.1 \mathrm{M}$ PBS. Brains were then postfixed overnight in $4 \%(\mathrm{w} / \mathrm{v})$ paraformaldehyde in PBS at $4^{\circ} \mathrm{C}$, followed by $12-24 \mathrm{~h}$ in PBS at $4^{\circ} \mathrm{C}$. Brains were cut coronally using a vibrating microtome (VT1200S, Leica Microsystems) into 150- $\mu \mathrm{m}$ thick sections. Sections were mounted on Superfrost Plus glass slides (VWR) with ProLong Gold antifade reagent (Invitrogen) as a mounting medium and covered with \#1.5 thickness cover glass (VWR).

\section{Dendritic spine and axonal bouton imaging and analysis}

Slides of histological sections prepared as described above were initially screened for GFP fluorescence using low-powered objectives on an Eclipse E800 microscope (Nikon), without knowledge of genotype. GFP ${ }^{+}$neurons in L2/3 of visual cortex were then identified by comparing landmarks observed via DAPI fluorescence and brightfield imaging (Eclipse E800 microscope), including the shape of the internal capsule, the hippocampus, thalamic structures, and cytoarchitectonic differences between the 

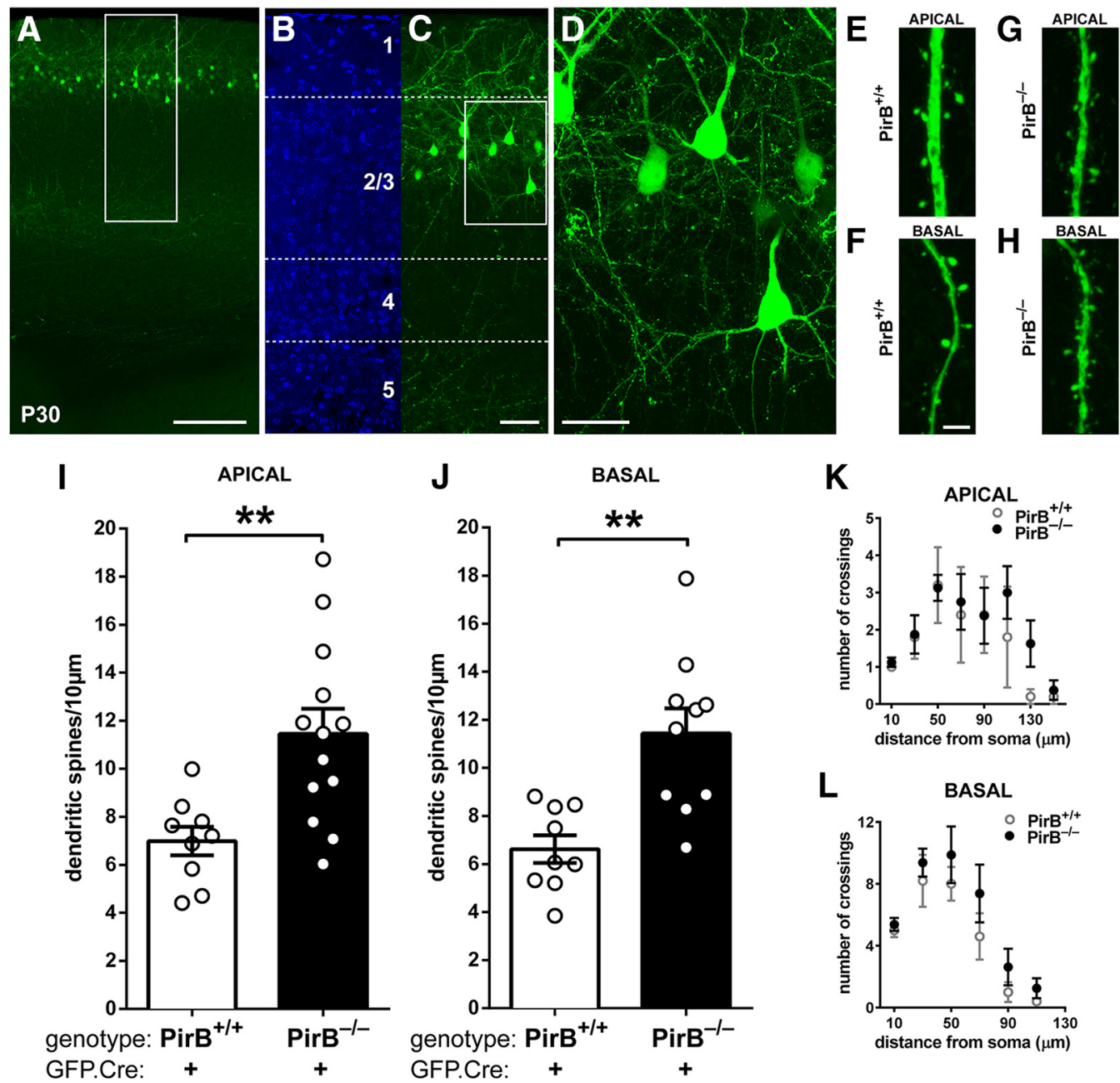

Figure 1. Density of dendritic spines on $L 2 / 3$ pyramidal neurons is greater in visual cortex of germline PirB ${ }^{-1-}$ mice than in $\mathrm{PirB}^{+/+}$ mice at P30. A, A low-magnification fluorescence micrograph of P30 mouse visual cortex showing GFP expression (green) in cells in L2/3 after GFP.Cre electroporation at E15.5. B, C, Higher-magnification views of boxed region shown in $\boldsymbol{A}$; DAPI nuclear counterstain $(\boldsymbol{B})$ shows that most of the GFP ${ }^{+}$neurons $(\boldsymbol{C})$ are in layer 2 and upper layer 3 . Soluble GFP fills the cells: cell bodies and dendrites, as well as descending axons clustering within layer 5 are all clearly visible. $\boldsymbol{D}$, High-magnification maximum intensity projection of boxed region shown in $\boldsymbol{C}$. Dendritic spines and axonal boutons are visible. $\boldsymbol{E}-\boldsymbol{H}$, High-magnification fluorescent micrographs showing apical $(\boldsymbol{E}, \boldsymbol{G})$ and basal $(\boldsymbol{F}, \boldsymbol{H})$ dendritic spines in $\mathrm{PirB}^{+/+}$and $\mathrm{PirB}^{-/-}$mice. $\boldsymbol{I}$, Apical dendritic spine density on $\mathrm{L} 2 / 3$ pyramidal neurons of $\mathrm{PirB}^{-1-}$ visual cortex is elevated compared with $\mathrm{PirB}^{+/+}\left(\mathrm{PirB}^{+/+} \mathrm{GFP}^{+} ; \mathrm{Cre}^{+}: 7.0 \pm 0.6\right.$ dendritic spines/10 $\mu \mathrm{m}$ of dendrite length, $n=9$ cells, 5 mice; PirB ${ }^{-1-}:$ GFP $^{+} ;$Cre $^{+}: 11.5 \pm 1.0, n=13$ cells, 5 mice; $p=0.004^{a}$, one-way ANOVA with post hoc Bonferroni's multiple comparisons). $\boldsymbol{J}$, Basal dendritic spine density is also increased in $\mathrm{PirB}^{-/-}$mice compared with $\mathrm{PirB}^{+/+}$mice $\left(\mathrm{PirB}^{+/+}\right.$ $\mathrm{GFP}^{+} ; \mathrm{Cre}^{+}: 6.6 \pm 0.6$ dendritic spines $/ 10 \mu \mathrm{m}$ of dendrite length, $n=9$ cells, 5 mice; $\mathrm{PirB}^{-/-} \mathrm{GFP}^{+} ; \mathrm{Cre}^{+}: 11.4 \pm 1.1, n=10$ cells, 5 mice; $p=0.002^{\mathrm{b}}$, one-way ANOVA with post hoc Bonferroni's multiple comparisons). $\boldsymbol{K}$, $\boldsymbol{L}$, Sholl analysis reveals no significant changes in apical $(\boldsymbol{K})$ or basal $(\boldsymbol{L})$ dendritic branching between $\mathrm{PirB}^{+/+}$and PirB ${ }^{-/-} \mathrm{L} 2 / 3$ neurons $\left(\mathrm{PirB}^{+/+} \mathrm{GFP}^{+} ; \mathrm{Cre}^{+}: n=5\right.$ cells, 3 mice; PirB ${ }^{-1-} \mathrm{GFP}^{+} ; \mathrm{Cre}^{+}: n=8$ cells, 5 mice; $p=0.2443^{\mathrm{c}}(\boldsymbol{K}), p=0.0574^{\mathrm{d}}(\boldsymbol{L})$, two-way ANOVA with repeated measures). $* * p<$ 0.01. Scale bars: $\boldsymbol{A}, 0.2 \mathrm{~mm} ; \boldsymbol{B}, \boldsymbol{C}, 50 \mu \mathrm{m} ; \boldsymbol{D}, 25 \mu \mathrm{m} ; \boldsymbol{E}-\boldsymbol{H}, 3 \mu \mathrm{m}$.

cortical layers (Paxinos and Franklin, 2008). Labeled cells with low expression levels of GFP and without complete primary dendritic arbors were excluded from further imaging. High-resolution images of apical and basal dendrites of $L 2 / 3$ pyramidal neurons in visual cortex, and of continuous $100-300 \mu \mathrm{m}$ segments of descending axons in L5, were taken on an SP2 or SP8 confocal microscope (Leica Microsystems), or on a two-photon microscope (Prairie Technologies); $63 \times / 1.40$ numerical aperture (NA) oil-immersion (Leica) or $60 \times / 1.1 \mathrm{NA}$ water-immersion (Prairie) objectives were used. Images were acquired at or over the theoretical Nyquist sampling rate for each objective used $(\sim 71 \mathrm{~nm} /$ pixel). All dendritic spine and axonal bouton analysis was performed manually while blind to genotype using ImageJ software (National Institutes of Health); manual tracing with ImageJ Simple Neurite Tracer plugin was used for length measurement of neurites. Axonal boutons were identified as in De Paola et al. (2006).

\section{Sholl analysis}

Images acquired by two-photon microscopy using $10 \times$ or $40 \times$ objectives (Prairie) that contained the entire 
L2/3 neuron dendritic arbor in a $150-\mu \mathrm{m}$-thick section were used for Sholl analysis (Sholl, 1953). For each cell, concentric circles were drawn at 10, 30, 50, 70, 90, 110, and $130 \mu \mathrm{m}$ from the geometric center of the soma (0 $\mu \mathrm{m})$, using the Concentric Circles ImageJ plugin. The number of crossings of dendritic branches belonging to individual cells through each circle were counted, and used as the measure of the complexity of the dendritic arbor.

\section{Assessment of neuronal labeling density resulting from} electroporations

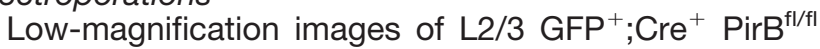
neurons were acquired (Eclipse E800 microscope) that included all GFP ${ }^{+}$neurons within a $0.5 \mathrm{~mm}$ radius of a $\mathrm{GFP}^{+}$neuron of interest. For each cell, concentric circles were drawn at $50 \mu \mathrm{m}$ intervals from the geometric center of the soma $(0 \mu \mathrm{m})$, using the Concentric Circles ImageJ plugin. The number of $\mathrm{GFP}^{+}$cells located within each ring (e.g., $50-100 \mu \mathrm{m}$ ) was then counted to derive a density versus distance measurement of distribution of the electroporated neighboring cells surrounding a neuron of interest (Fig. 2F).

\section{Electrophysiology}

At postnatal day 28 (P28) to P32, $\mathrm{PirB}^{+/+}$and $\mathrm{PirB}^{\mathrm{fl} / \mathrm{fl}}$ mice that had been electroporated in utero at E15.5 were overdosed with an intraperitoneal injection of a ketamine (132 mg/kg; Phoenix), xylazine (14 mg/kg; Akorn), acepromazine $(0.2 \mathrm{mg} / \mathrm{kg}$; Boehringer Ingelheim) cocktail; after deep anesthesia, mice were decapitated. Brains were immediately removed and immersed in $N$-methyl-Dglucamine (NMDG)-based ice-cold slicing buffer, to minimize damage from excitotoxicity and hypoxia (composition: $135 \mathrm{~mm} \mathrm{NMDG}, 1 \mathrm{~mm} \mathrm{KCl}, 1.2 \mathrm{~mm} \mathrm{KH}_{2} \mathrm{PO}_{4}, 1.5$ $\mathrm{mm} \mathrm{MgCl}, 0.5 \mathrm{mM} \mathrm{CaCl}_{2}, 20 \mathrm{~mm}$ choline bicarbonate, and $10 \mathrm{~mm}$ glucose, $\mathrm{pH} 7.4$, equilibrated with $95 \% \mathrm{O}_{2}$ and $5 \%$ $\mathrm{CO}_{2}$ ). Brains were cut coronally at $400 \mu \mathrm{m}$, using a vibrating microtome (VT1000S, Leica Microsystems). Sections were transferred to a recovery chamber containing highmagnesium artificial CSF (ACSF; composition: $125 \mathrm{~mm}$ $\mathrm{NaCl}, 26 \mathrm{~mm} \mathrm{NaHCO}$, $2.3 \mathrm{~mm} \mathrm{KCl}, 1.26 \mathrm{~mm} \mathrm{KH}_{2} \mathrm{PO}_{4}, 4.0$ $\mathrm{mM} \mathrm{MgCl}$, $2.5 \mathrm{mM} \mathrm{CaCl}_{2}$, and $20 \mathrm{~mm}$ glucose, $\mathrm{pH} 7.4$, equilibrated with $95 \% \mathrm{O}_{2}$ and $5 \% \mathrm{CO}_{2}$ ). Slices recovered at $37^{\circ} \mathrm{C}$ for $30 \mathrm{~min}$, and an additional $30 \mathrm{~min}$ at room temperature before recording (Crozier et al., 2007; Djurisic et al., 2013).

The whole-cell patch-clamp technique was used to record miniature EPSCs (mEPSCs) from individual pyramidal cells in slices containing primary visual cortex and binocular zone. Single, GFP-labeled or unlabeled L2/3 pyramidal neurons in visual cortex were visualized using infrared differential interference contrast illumination combined with fluorescent illumination in an Olympus BX51WI Microscope via a $60 \times$ water-immersion objective coupled with an additional $2 \times$ zoom lens $(120 \times$ final magnification). For GFP ${ }^{-}$cells, only those with pyramidal-shaped somata and a visible apical dendrite oriented perpendicular to the pial surface were selected for recordings. The external bath solution (ACSF) was maintained at $\sim 30^{\circ} \mathrm{C}$, and bubbled with $95 \% \mathrm{O}_{2}, 5 \% \mathrm{CO}_{2}$ for the duration of the experiment. Patch-clamp electrodes (1.5-4.2 $\mathrm{M} \Omega$ ) were filled with cesium-based intracellular solution (composition: $135 \mathrm{~mm} \mathrm{CsCl}, 10 \mathrm{~mm}$ HEPES, $1 \mathrm{~mm}$ EGTA, $4 \mathrm{~mm}$ Mg-ATP, 0.4 mm Na-GTP, pH 7.4 with $\mathrm{NaOH}$ ). To reveal the morphology of neurons from which mEPSCs were recorded, biocytin (catalog \#B4261, Sigma-Aldrich) was added to the intracellular solution at a final concentration of $5 \mathrm{mg} / \mathrm{ml}$; after recording, sections were fixed in $4 \%$ paraformaldehyde overnight, followed by permeabilization and staining with Texas Red-conjugated avidin (catalog \#A-2006, Vector Laboratories; 1:10). Once in wholecell mode, the pipette solution equilibrated with the cell contents for 5-10 min before recording. Miniature excitatory postsynaptic AMPA currents were isolated pharmacologically using $1 \mu \mathrm{m}$ tetrodotoxin (catalog \#1078, Tocris Bioscience), $50 \mu \mathrm{M}$ aminophosphonopentanoic acid (catalog \#A5282, Sigma-Aldrich), and $10 \mu \mathrm{M}$ gabazine (SR95531; catalog \#1262, Tocris Bioscience). Series resistance was 9-20 M . The low-noise AxoPatch 200B Patch-Clamp Amplifier, DigiData 1322A Digitizer, and Clampex Software (Molecular Devices) were used for data collection. Before analysis, recordings across all conditions were filtered with a $60 \mathrm{~Hz}$, three-harmonic, 100 cycle electrical interference filter (Molecular Devices), as well as a Gaussian, 53 coefficient low-pass filter (setting, $-3 \mathrm{~dB}$ to $2 \mathrm{kHz}$; Molecular Devices). Analysis of mEPSCs was performed using MiniAnalysis version 6.0.7 (Synaptosoft), and blinded to both genotype and cell identity (i.e., GFP ${ }^{+}$ vs $\mathrm{GFP}^{-}$). Cells with cell capacitance of $60 \mathrm{pF}$ and/or leak current more negative than $-150 \mathrm{pA}$ were excluded from the analysis. Root mean square (rms) baseline noise was calculated from three different places during the $10 \mathrm{~min}$ ute recording, and was $<3 \mathrm{pA}$. Automatic detection parameters in MiniAnalysis were adapted from the studies of Xu et al. (2009a) and Muhia et al. (2012), and were as follows: threshold was set to 4 times the rms noise value; the period to search for a local maximum was $20 \mathrm{~ms}$; the time before peak to establish baseline was $5 \mathrm{~ms}$; the period to search a decay time was $5 \mathrm{~ms}$; the fraction of the peak to find a decay time was 0.5 ; the period to average baseline was $2 \mathrm{~ms}$; the area threshold was five times the rms noise value; and the number of points to average to establish the peak was 3 . Continuous automatic analysis was run during 1-2 min of the $10 \mathrm{~min}$ recording in which the leak current was most stable; detected events were manually inspected to eliminate false positives.

\section{Statistics}

All statistical analyses and graphs were performed with GraphPad Prism software, and power analyses were performed using G*Power software (Heinrich-Heine-Universität Düsseldorf, Düsseldorf, Germany; http://www.gpower.hhu.de/; Faul et al., 2007, 2009). Data are presented as the mean \pm SEM; sample size $(n)$ is the number of cells analyzed, followed by the number of mice used for the entire sample, unless noted otherwise in the text (Table 1). Analyses were performed blinded to genotype and condition. 
Table 1: Statistical table

\begin{tabular}{|c|c|c|c|c|}
\hline & & & Power & \\
\hline & Data structure & Type of test & $(\alpha=0.05)$ & $p$ value \\
\hline a (Figs. 1I, 2G) & $\begin{array}{l}\text { Normality assumed (Levene's } \\
\text { test } p=0.118)\end{array}$ & $\begin{array}{l}\text { One-way ANOVA with Bonferroni's } \\
\text { multiple-comparisons post hoc }\end{array}$ & 0.9403 & 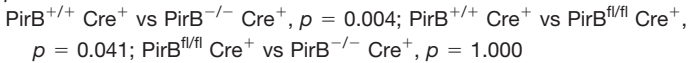 \\
\hline b (Figs. $1 \mathrm{~J}$ and $2 \mathrm{H}$ ) & $\begin{array}{l}\text { Normality assumed (Levene's } \\
\text { test } p=0.233 \text { ) }\end{array}$ & $\begin{array}{l}\text { One-way ANOVA with Bonferroni's } \\
\text { multiple-comparisons post hoc }\end{array}$ & 0.9733 & 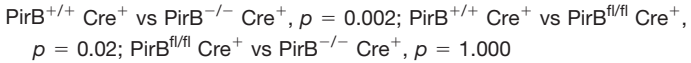 \\
\hline c (Fig. 1K) & Normal distribution & $\begin{array}{l}\text { Two-way ANOVA with } \\
\text { repeated measures }\end{array}$ & 0.2383 & 0.2443 \\
\hline d (Fig. 1L) & Normal distribution & $\begin{array}{l}\text { Two-way ANOVA with } \\
\text { repeated measures }\end{array}$ & 0.9534 & 0.0574 \\
\hline e (Fig. 2K) & Normal distribution & $\begin{array}{l}\text { Two-way ANOVA with } \\
\text { repeated measures }\end{array}$ & 0.0501 & 0.8864 \\
\hline f (Fig. 2L) & Normal distribution & $\begin{array}{l}\text { Two-way ANOVA with } \\
\text { repeated measures }\end{array}$ & 0.0521 & - \\
\hline g (Fig. 3C) & $\begin{array}{l}\text { Normality assumed (Levene's } \\
\quad \text { test } p=0.494)\end{array}$ & $\begin{array}{l}\text { One-way ANOVA with Bonferroni's } \\
\text { multiple-comparisons post hoc }\end{array}$ & 0.9988 & 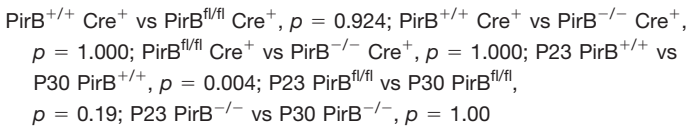 \\
\hline h (Fig. 4G) & Normality not assumed & Mann-Whitney & 0.8509 & 0.0058 \\
\hline i (Fig. 4l) & Normality not assumed & Mann-Whitney & 0.1634 & 0.3286 \\
\hline j (Fig. 4K) & Normality not assumed & Mann-Whitney & 0.0961 & 0.4940 \\
\hline k (Fig. 4M) & Normality not assumed & Mann-Whitney & 0.1855 & 0.3918 \\
\hline I (Fig. 5E) & Normality not assumed & Wilcoxon signed-rank & 0.9959 & 0.0060 \\
\hline m (Fig. 5F) & Normality not assumed & Wilcoxon signed-rank & 0.1109 & 0.7722 \\
\hline n (Fig. 6C) & $\begin{array}{l}\text { Normality assumed (Levene's } \\
\quad \text { test } p=0.869)\end{array}$ & $\begin{array}{l}\text { One-Way ANOVA with Bonferroni's } \\
\text { multiple comparisons post hoc }\end{array}$ & 0.1347 & $\begin{array}{l}\text { PirB }^{+/+} \text {Cre }^{+} \text {vs } \text { PirB }^{\mathrm{fl} / f l} \mathrm{Cre}^{+}, p=1.000 ; \mathrm{PirB}^{+/+} \mathrm{Cre}^{+} \text {vs } \mathrm{PirB}^{-/-} \mathrm{Cre}^{+}, \\
\quad p=1.000 ; \mathrm{PirB}^{\mathrm{fl} / \mathrm{fl}} \mathrm{Cre}^{+} \text {vs } \text { PirB }^{-/-} \mathrm{Cre}^{+}, p=1.000\end{array}$ \\
\hline
\end{tabular}

\section{Results}

To examine whether PirB expression, specifically in pyramidal neurons, is sufficient to regulate spine density, $\mathrm{PirB}^{+/+}, \mathrm{PirB}^{-/-}$, and $\mathrm{PirB}^{\mathrm{fl} / \mathrm{fl}}$ mice were studied in combination with in utero electroporation of a GFP.Cre expression vector to selectively target a subset of excitatory pyramidal neurons in $\mathrm{L} 2 / 3$ at the time of their genesis. Because excitatory neurons from different cortical layers are generated sequentially in the cortical ventricular zone (McConnell and Kaznowski, 1991; Chen et al., 2008; Greig et al., 2013), neurons of each cortical layer can be targeted by timing in utero electroporations of the ventricular zone; at E15.5, L2/3 pyramidal neurons are targeted exclusively (Saito and Nakatsuji, 2001). Glia and interneurons are not transfected since the production of glial cells peaks around birth, while interneurons are generated in the ganglionic eminence and not in the ventricular zone (Anderson et al., 1997; Nery et al., 2002). Layer 2/3 pyramidal neurons are of particular interest because of the changes previously observed in $\mathrm{PirB}^{-/-}$mice in cellular mechanisms of synaptic plasticity at L4 to L2/3 synapses, in mEPSC frequency recorded from L2/3 neurons, and in OD plasticity as assessed in L2/3 using intrinsic signal imaging (Djurisic et al., 2013).

\section{L2/3 pyramidal neurons of PirB $^{-/-}$mice have elevated dendritic spine density}

This first experiment was designed to examine whether spine density on $\mathrm{L} 2 / 3$ neurons in $\mathrm{PirB}^{-1-}$ mice is increased at P30. At E15.5, $\mathrm{PirB}^{+/+}$or $\mathrm{PirB}^{-/-}$embryos were injected with a DNA construct (GFP.Cre) expressing GFP, as well as Cre recombinase under a separate promoter and subjected to electroporation. Note that this initial experiment was not performed in mice carrying a conditional allele of PirB. Consequently, neurons are labeled with GFP to permit the assessment of morphology, but Cre expression does not drive excision, and instead serves as a control for subsequent experiments.

Electroporation at E15.5 results in laminar-specific GFP labeling of $\mathrm{L} 2 / 3$ pyramidal neurons in primary visual cortex at P30 (Fig. 1A-D). Dendritic spines were extensively $\mathrm{GFP}^{+}$labeled as viewed using confocal microscopy (Fig. $1 E-H)$, permitting assessment of density. Spine density on $\mathrm{L} 2 / 3$ pyramidal neurons of $\mathrm{PirB}^{-/-}$mice is significantly elevated, relative to that in $\mathrm{PirB}^{+/+}$mice; spine density is $64 \%$ greater on apical dendrites in $\mathrm{PirB}^{-/-}$versus $\mathrm{PirB}^{+/+}$ (Fig. 1/), and $73 \%$ greater on basal dendrites (Fig. 1J). The excess dendritic spines are likely to be sites of functional synapses, since EM studies from mouse visual cortex show that $>95 \%$ of dendritic spines have machinery needed for synaptic transmission: they are positive for PSD-95 and apposed by presynaptic active zones (Arellano et al., 2007). Moreover, the spine density increase observed here in $\mathrm{PirB}^{-1-}$ mouse visual cortex is consistent with the previously reported increase in mEPSC frequency recorded from L2/3 pyramidal neurons-a sensitive measure of the density of functional excitatory synapses (Djurisic et al., 2013).

These significant changes in dendritic spine density in PirB ${ }^{-1-}$ neurons suggest that other aspects of neuronal morphology may also be altered. To examine this possibility, the dendritic complexity of $\mathrm{GFP}^{+} \mathrm{L} 2 / 3$ pyramidal neurons in visual cortex of $\mathrm{PirB}^{+/+}$and $\mathrm{PirB}^{-1-}$ mice was assessed using Sholl analysis (Sholl, 1953). Apical and basal dendritic complexity was unaltered in $\mathrm{PirB}^{-1-}$ mice relative to $\mathrm{PirB}^{+/+}$mice (Fig. $1 K, L$ ). Together, these observations demonstrate that the changes in mEPSC frequency observed previously (Djurisic et al. 2013) are accompanied by changes in spine density but not dendritic complexity, in L2/3 pyramidal neurons. 


\section{Sparse deletion in PirB ${ }^{\mathrm{fl} / \mathrm{fl}}$ mice results in elevated spine density on isolated L2/3 pyramidal neurons}

An increase in both spine density (Fig. 1) and in functional excitatory synapses (Djurisic et al., 2013) is observed in $\mathrm{L} 2 / 3$ pyramidal neurons of $\mathrm{PirB}^{-1-}$ versus $\mathrm{PirB}^{+/+}$mice. To examine whether this increase is due to the loss of PirB from the very cells where dendritic spines were counted or to the loss of PirB in other presynaptic or non-neuronal cells, a mosaic approach was used to delete PirB from isolated L2/3 pyramidal neurons. PirB ${ }^{\mathrm{fl} / \mathrm{fl}}$ mice were electroporated with GFP.Cre at E15.5, and then studied at P30 (Fig. 2A-E). In PirB ${ }^{\mathrm{fl} / \mathrm{fl}}$ mice, cells expressing GFP coexpress Cre recombinase, which drives the excision of the floxed PirB alleles.

In a subset of $\mathrm{PirB}^{\mathrm{fl} / \mathrm{fl}}$ mice electroporated with the GFP.Cre vector (see Materials and Methods), a very sparse distribution of PirB knock-out neurons embedded in a "sea" of cells containing intact PirB alleles was obtained (Fig. 2A-E). To quantify the sparseness of PirB deletion, the density of GFP ${ }^{+}$cells in V1 was measured by counting the number of labeled cells in a series of concentric circles surrounding the cell selected for spine analysis (Fig. 2F). Using this Sholl analysis, we determined that for the majority of neurons analyzed, there were almost no neighboring $\mathrm{GFP}^{+}$neurons located within a radius of $50 \mu \mathrm{m}$, and then within each $50 \mu \mathrm{m}$ increment outward from the cell under analysis, there was an average of only one additional labeled neuron at most. In contrast, the density of labeled cells was far greater in Figure 1, where a larger volume of DNA was injected. Thus, electroporation could result in a very sparse deletion of PirB from isolated L2/3 pyramidal neurons, permitting us to examine a cell-intrinsic function for PirB in regulating dendritic spine density.

At P30, spine density on isolated $\mathrm{GFP}^{+} ; \mathrm{Cre}^{+} \mathrm{L} 2 / 3$ pyramidal neurons in visual cortex of sparsely electroporated $\mathrm{Pir} \mathrm{B}^{\mathrm{fl} / \mathrm{fl}}$ mice was significantly elevated, compared with $\mathrm{GFP}^{+} ; \mathrm{Cre}^{+}$neurons from control $\mathrm{PirB}^{+/+}$mice, in which PirB excision has not occurred. In addition, density was almost identical to that observed on L2/3 dendrites of $\mathrm{GFP}^{+} ; \mathrm{Cre}^{+}$neurons from $\mathrm{PirB}^{-1-}$ mice, as shown in Figure $2 G-J$, which compares data from all three genotypes. There are significant spine density increases along both apical $(52 \%)$ and basal $(60 \%)$ dendrites in $\mathrm{PirB}^{\mathrm{fl} / \mathrm{fl}}$ neurons that have undergone recombination and lack PirB, compared with L2/3 $\mathrm{GFP}^{+}$; $\mathrm{Cre}^{+}$neurons in $\mathrm{PirB}^{+/+}$mice that have not undergone recombination and express PirB normally (Fig. 2G,H). Multiple comparisons with one-way ANOVA followed by Bonferroni post hoc test reveals significant differences between the density of spines on apical dendrites between $\operatorname{PirB}^{+/+}$versus $\operatorname{PirB}^{\mathrm{fl} / / \mathrm{l}}$ mice $(p=$ $0.041)$ and $\mathrm{PirB}^{+/+}$versus $\mathrm{PirB}^{-/-}$mice $(p=0.004)$, but not PirB ${ }^{\mathrm{fl} / f \mathrm{l}}$ versus $\mathrm{PirB}^{-1-}$ mice $(p=1.00)$. Similar statistically significant differences for basal dendritic spines were revealed by post hoc analysis, as follows: $\mathrm{PirB}^{+/+}$ versus $\mathrm{PirB}^{\mathrm{fl} / \mathrm{fl}}$ mice $(p=0.02)$ and $\mathrm{PirB}^{+/+}$versus $\mathrm{PirB}^{-/-}$ mice $(p=0.002)$, but not $\operatorname{PirB}^{f / / f 1}$ versus $\operatorname{PirB}^{-/-}$mice $(p=$ 1.00).

The dendritic arborization of $\mathrm{GFP}^{+} ; \mathrm{Cre}^{+}$cells in $\mathrm{PirB}^{\mathrm{fl} / f \mathrm{l}}$ mice versus $\mathrm{GFP}^{+}$; $\mathrm{Cre}^{+}$cells in $\mathrm{PirB}^{+/+}$mice was also examined. No significant differences in apical or basal dendritic Sholl profiles (Sholl, 1953) were observed (Fig. $2 K, L)$, underscoring a selective effect of PirB deletion on spine density in isolated L2/3 neurons.

\section{Dendritic spine density on L2/3 pyramidal cells in all genotypes is similar at P23}

The elevated spine density observed at P30 in mice lacking PirB could arise from changes in dendritic spine formation and/or from a failure of pruning. To distinguish these possibilities, the sparse GFP.Cre electroporation experiment described above was repeated, but the density of spines was assessed 1 week earlier at P23, during the period of synaptic pruning and when dendritic spine density in WT visual cortex is highest based on previous Golgi cell and EM studies (Ruiz-Marcos and Valverde, 1969; Markus and Petit, 1987).

The dendrites and spines of $L 2 / 3$ pyramidal neurons at P23 were extensively GFP labeled (Fig. $3 A, B$ ) subsequent to electroporation at E15.5. Multiple comparisons with one-way ANOVA and Bonferroni post hoc test did not reveal any significant differences between the density of spines for all three genotypes (Fig. 3C,D). Moreover, dendritic spine density for $\mathrm{PirB}^{+/+}$is almost twice as high at P23 (Fig. 3C: $\sim 13$ spines/10 $\mu \mathrm{m})$ than at P30 $(\sim 7$ spines $/ 10 \mu \mathrm{m})$. In contrast to wild-type, there are no statistically significant differences between $\mathrm{Pir}^{\mathrm{fl} / \mathrm{fl}}$ mice at $\mathrm{P} 23$ versus $\mathrm{P} 30$, or $\mathrm{PirB}^{-1-}$ mice at $\mathrm{P} 23$ versus $\mathrm{P} 30$, strongly suggesting that spine pruning is deficient in $L 2 / 3$ neurons lacking PirB.

\section{Sparse PirB excision results in increased mEPSC frequency recorded from isolated L2/3 pyramidal neurons at P30}

In $\mathrm{PirB}^{-/-}$mice, the increase in spine density on L2/3 pyramidal neurons (Fig. 1) is accompanied by an increase in mEPSC frequency, a measure of the density of functional excitatory synapses (Djurisic et al., 2013). Is the increase in dendritic spine density observed following sparse deletion in PirB ${ }^{\mathrm{fl} / \mathrm{fl}}$ mice similarly accompanied by an increase in mEPSC frequency? To assess the strength and number of functional excitatory synaptic inputs, the frequency and amplitude of mEPSCs in acute slices from visual cortex of $\mathrm{PirB}^{\mathrm{fl} / \mathrm{fl}}$ mice was assessed using the patch-clamp technique (Fig. 4). In this experiment, both labeled $\left(\mathrm{GFP}^{+} ; \mathrm{Cre}^{+}\right)$and unlabeled $\left(\mathrm{GFP}^{-} ; \mathrm{Cre}^{-}\right)$neurons could be recorded and compared in the same slice (Fig. $4 A-D$ ); cells were also labeled via patch pipette with biocytin to confirm the pyramidal identity of $\mathrm{GFP}^{-}$; $\mathrm{Cre}^{-}$cells targeted for recordings (Fig. 4E,F). The frequency of mEPSCs in $\mathrm{GFP}^{+} ; \mathrm{Cre}^{+}$neurons was $69 \%$ higher than in $\mathrm{GFP}^{-}$; $\mathrm{Cre}^{-}$controls (Fig. 4G,H), with no measurable change in $\mathrm{mEPSC}$ amplitude (Fig. $4 /, J)$.

Miniature EPSC frequencies and amplitudes recorded from $\mathrm{GFP}^{+} ;$Cre $^{+}$neurons in $\mathrm{PirB}^{\mathrm{fl} / \mathrm{fl}}$ mice (Fig. 4G-J) were similar to those of $L 2 / 3$ pyramidal neurons in germline $\mathrm{PirB}^{-1-}$ slices (Djurisic et al., 2013). In addition, GFP ${ }^{-}$; $\mathrm{Cre}^{-}$neurons in $\mathrm{PirB}^{\mathrm{fl} / \mathrm{fl}}$ slices had mEPSC frequency and amplitudes similar to $\mathrm{PirB}^{+/+}$slices (Fig. 4, compare G-J, $K-N$ ). These results indicate that the in utero electropora- 


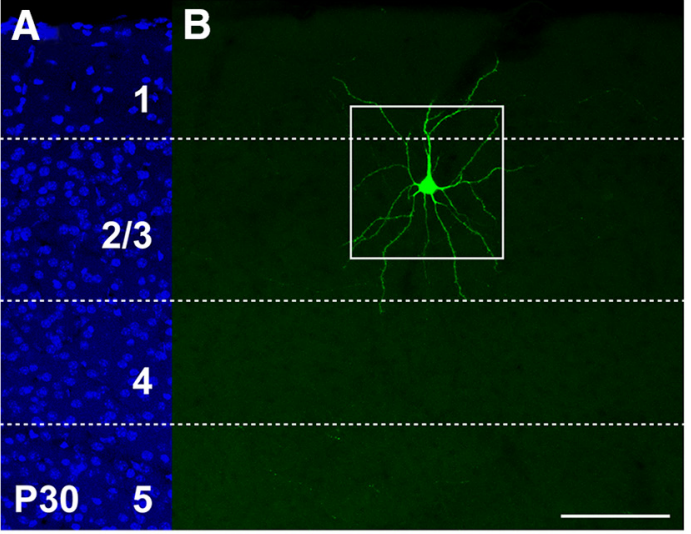

$\mathbf{F}$

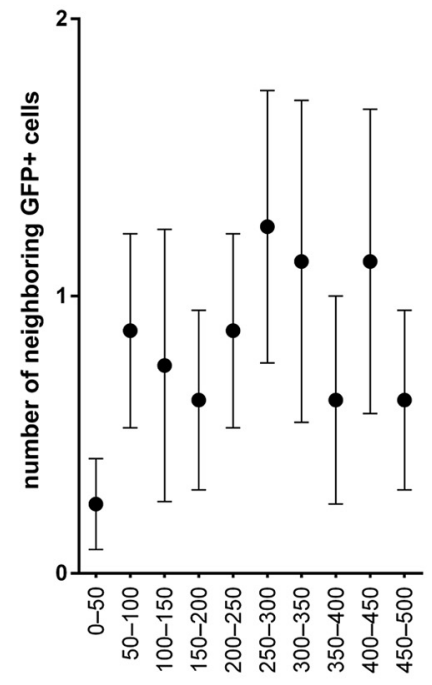

C

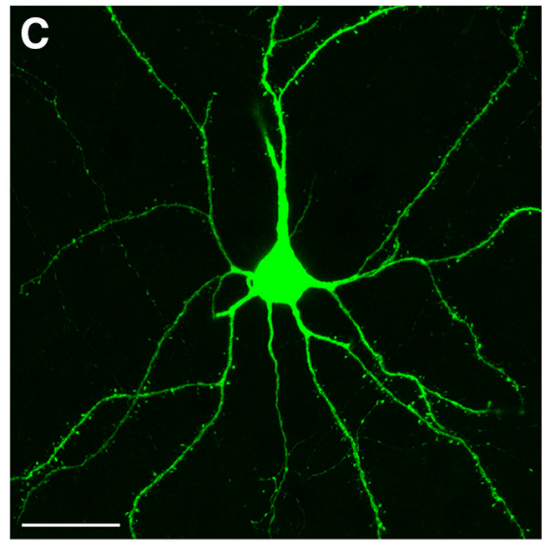

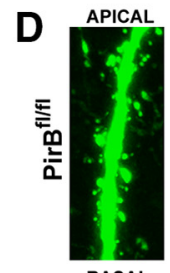

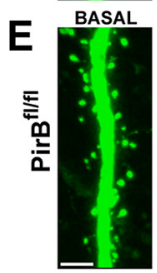

H
G

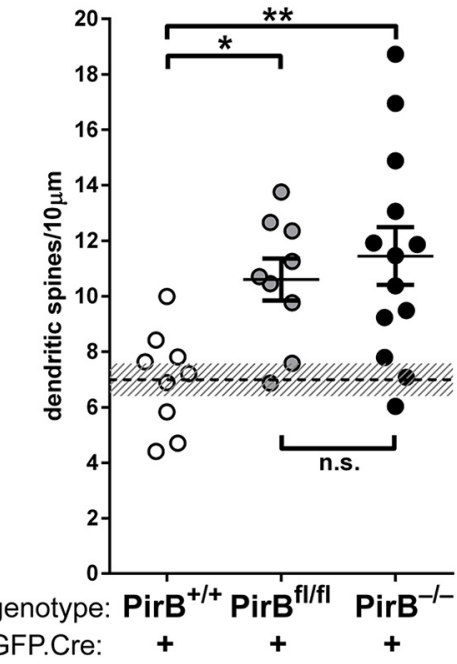

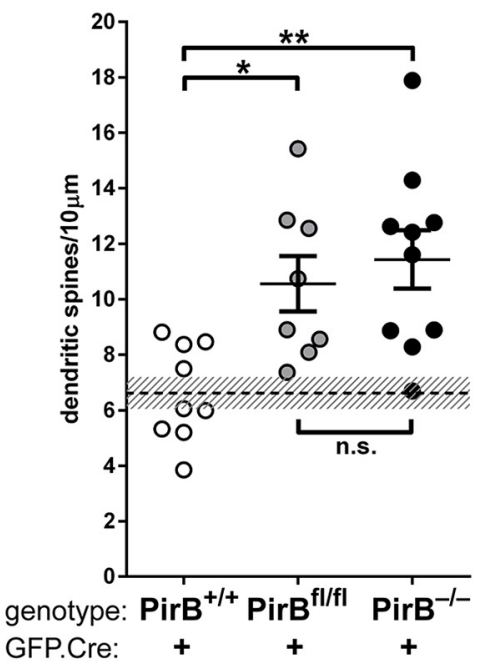
distance from soma $(\mu \mathrm{m})$
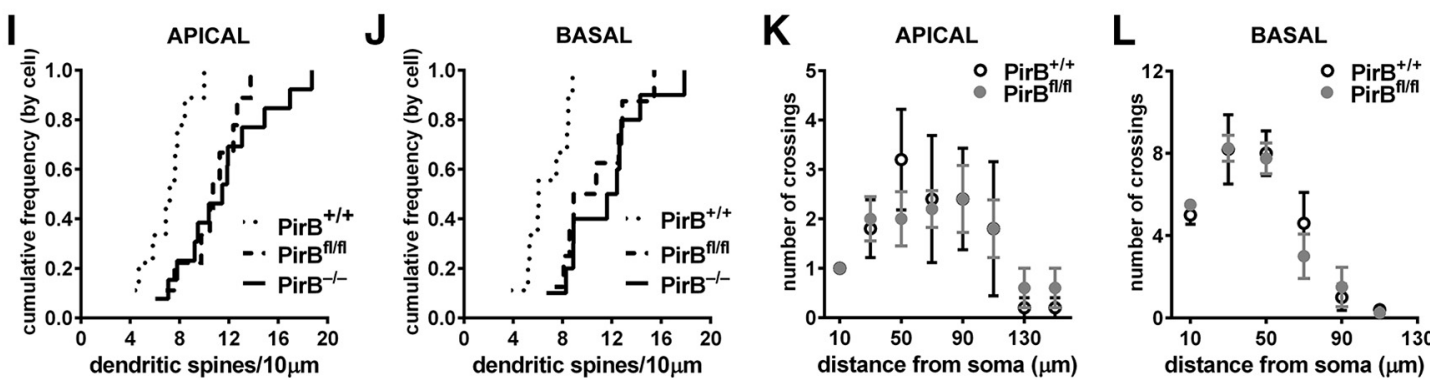

Figure 2. Dendritic spine density at $\mathrm{P} 30$ is elevated on isolated $\mathrm{PirB}^{-/-}$neurons in layer $2 / 3$ after sparse excision of PirB at E15.5. A, B, Fluorescent micrographs at P30 of nuclear counterstain (DAPI; $\boldsymbol{A}$ ) and an isolated L2/3 pyramidal neuron electroporated with GFP.Cre (B) from a visual cortex section from a P30 PirB ${ }^{\mathrm{fl} / \mathrm{fl}}$ mouse. C, High-magnification maximum intensity projection of the boxed area in $\boldsymbol{B}$. D, $\boldsymbol{E}$, Zoomed-in high-magnification micrographs of portions of apical $(\boldsymbol{D})$ and basal $(\boldsymbol{E})$ dendrites showing dendritic spines in PirB $\mathrm{B}^{\mathrm{fl} / \mathrm{fl}}$ mice. $\boldsymbol{F}$, Number of neighboring $\mathrm{GFP}^{+} ; \mathrm{Cre}^{+}$cells as a function of distance from a neuron of interest in PirB ${ }^{\mathrm{fl} / \mathrm{fl}}$ tissue $(n=8 \mathrm{cells}, 7 \mathrm{mice})$. The graph shows that, on average, there was only one $\mathrm{GFP}^{+} ; \mathrm{Cre}^{+}$cell in every $50 \mu \mathrm{m}$ increment analyzed. G, Spine density on apical dendrites is greater in $\mathrm{GFP}^{+} ; \mathrm{Cre}^{+}$neurons from PirB $\mathrm{fl}^{\mathrm{f} / \mathrm{fl}}$ mice than $\mathrm{PirB}^{+/+}$mice $\left(\mathrm{PirB}^{+/+}: 7.0 \pm 0.6\right.$ dendritic spines $/ 10 \mu \mathrm{m}$ of dendritic length, $n=9$ cells, 5 mice; same data as in Fig. $1 /$ PirB $^{\mathrm{fl} / f 1}, \mathrm{GFP}^{+} ; \mathrm{Cre}^{+}: 10.6 \pm 0.8, n=9$ cells, 7 mice; PirB ${ }^{-/-}, \mathrm{GFP}^{+} ;$Cre $^{+}: 11.5 \pm 1.0, n=13$ cells,

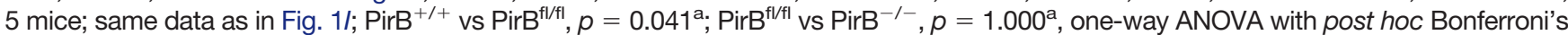
multiple comparisons). $\boldsymbol{H}$, Basal dendritic spine density is greater in $\mathrm{GFP}^{+} ; \mathrm{Cre}^{+}$neurons from PirB' ${ }^{\mathrm{fl} / \mathrm{fl}}$ mice than $\mathrm{PirB}^{+/+}$mice $\left(\mathrm{PirB}^{+/+}: 6.6\right.$ \pm 0.6 dendritic spines $/ 10 \mu \mathrm{m}$ of dendritic length, $n=9$ cells, 5 mice; data from Fig. $1 \mathrm{~J}$; PirB ${ }^{\mathrm{fl} / \mathrm{fl}}$, GFP ${ }^{+} ; \mathrm{Cre}^{+}: 10.6 \pm 1.0, n=8$ cells, 7 mice;

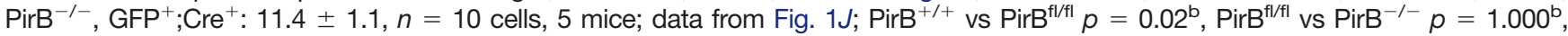
One-way ANOVA with post hoc Bonferroni's multiple comparisons). I, Cumulative histogram (by cell) of data presented in G. J, Cumulative histogram (by cell) of data presented in $\boldsymbol{H}$. $\boldsymbol{K}, \boldsymbol{L}$, Sholl analysis reveals no significant changes in apical $(\boldsymbol{K})$ or basal $(\boldsymbol{L})$ dendritic branching between $\mathrm{GFP}^{+} ; \mathrm{Cre}^{+} \mathrm{L} 2 / 3$ neurons from PirB ${ }^{+/+}$and PirB ${ }^{\mathrm{flfl}}$ mice $\left(\boldsymbol{K}: \mathrm{PirB}^{+/+}, n=5\right.$ cells, 3 mice; data from Fig. $1 K ;$ PirB ${ }^{\mathrm{flfl} / \mathrm{l}}, n=5$ cells, 3 mice, $p=0.8864^{\mathrm{e}} ; \boldsymbol{L}_{\text {: }}$ PirB $^{+/+}, n=5$ cells, 3 mice; data from Fig. $1 L$; PirB $^{\text {fl/til }}, n=4$ cells, 3 mice, $p=0.7799^{f}$, two-way ANOVA with repeated measures). *p $<0.05 ; * * p<0.01$. Scale bars: $\boldsymbol{A}, \boldsymbol{B}, 100 \mu \mathrm{m} ; \boldsymbol{C}, 25 \mu \mathrm{m} ; \boldsymbol{D}, \boldsymbol{E}, 3 \mu \mathrm{m}$. 

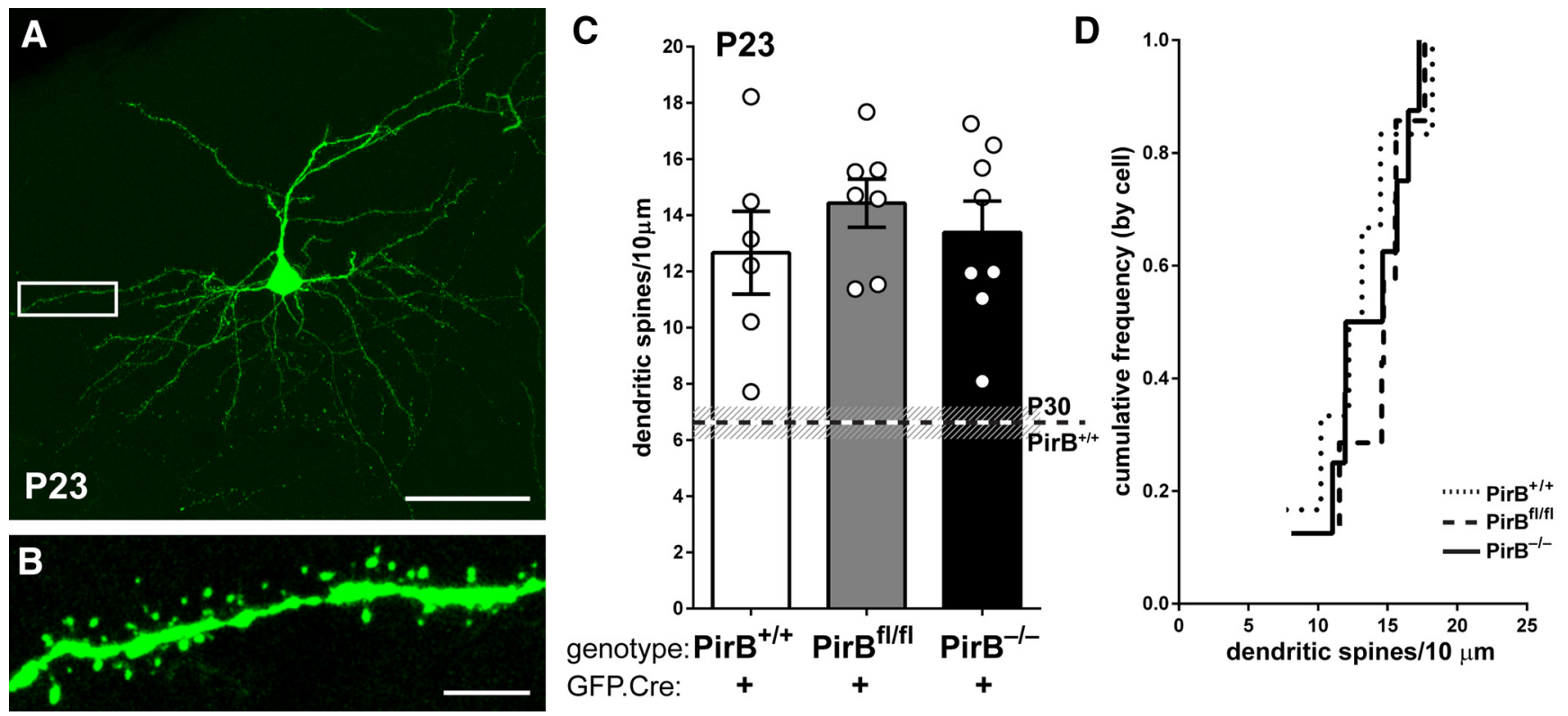

Figure 3. At P23, dendritic spine density on L2/3 pyramidal cells in $\mathrm{PirB}^{-/-}$visual cortex is similar to that of $\mathrm{PirB}^{+/+}$. $\boldsymbol{A}$, Fluorescent micrograph at P23, an age near the onset of spine pruning, showing an isolated L2/3 pyramidal neuron electroporated with GFP.Cre at E15.5. B. High-magnification, maximum-intensity projection of boxed area in $\boldsymbol{A}$ showing spines on basal dendrites of GFP ${ }^{+}$;Cre ${ }^{+}$ $\mathrm{L} 2 / 3$ neuron. $\boldsymbol{C}$, Basal dendrite spine density is higher in $\mathrm{PirB}^{+/+}$neurons at $\mathrm{P} 23$ than in $\mathrm{PirB}^{+/+}$neurons at $\mathrm{P} 30$ ( $\mathrm{P} 30$ data indicated by dotted line; data from Fig. $2 H)$; spine density from P23 PirB ${ }^{+/+}$is not different from PirB ${ }^{\mathrm{fl} / \mathrm{fl}}$ or PirB ${ }^{-/-}$neurons $\left(\mathrm{P}^{23} \mathrm{PirB}^{+/+}\right.$: 12.66 $\pm 1.5, n=6$ cells, 3 mice; P23 PirB ${ }^{\mathrm{fl} / \mathrm{fl}}: 14.43 \pm 0.9, n=7$ cells, 5 mice; P23 PirB ${ }^{-/-}: 13.39 \pm 1.1, n=8$ cells, 4 mice; P23 PirB ${ }^{+/+}$vs

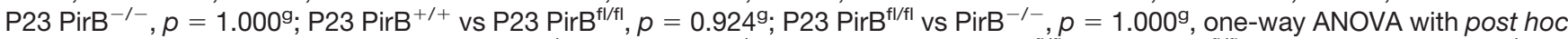
Bonferroni's multiple comparisons; P23 $\mathrm{PirB}^{+/+}$vs P30 $\mathrm{PirB}^{+/+}, p=0.004^{\mathrm{g}}$; P23 PirB ${ }^{\mathrm{fl} / \mathrm{fl}}$ vs P30 PirB ${ }^{\mathrm{fl} / \mathrm{fl}}, p=0.19^{9} ; \mathrm{P}^{2} 3 \mathrm{PirB}^{-/-}$vs P30 PirB ${ }^{-/-}, p=1.00^{9}$, one-way ANOVA with post hoc Bonferroni's multiple comparisons). $\boldsymbol{D}$, Cumulative histogram (by cell) of data presented in $\boldsymbol{C}$. Scale bars: $\boldsymbol{A}, 50 \mu \mathrm{m} ; \boldsymbol{B}, 5 \mu \mathrm{m}$.

tion technique by itself does not affect the development of functional excitatory synaptic inputs to L2/3 pyramidal neurons. To control for off-target effects of Cre recombinase and GFP expression on mEPSC recordings, we also examined mEPSC frequency and amplitude in $\mathrm{PirB}^{+/+}$ tissue subsequent to electroporation with GFP.Cre. In this case, Cre recombinase does not cause excision, and thus labeled and unlabeled cells differ only in their expression of GFP and Cre. Results show that $\mathrm{GFP}^{+} ; \mathrm{Cre}^{+}$neurons in $\mathrm{PirB}^{+/+}$slices do not differ significantly from $\mathrm{GFP}^{-} ; \mathrm{Cre}^{-}$ neurons in $\mathrm{PirB}^{+/+}$slices in either mEPSC frequency (Fig. $4 K, L$ ) or amplitude (Fig. $4 M, N$ ). This experiment demonstrates that the electroporation and expression of GFP and $\mathrm{Cre}$ in and of themselves do not alter detectably these electrophysiological properties of L2/3 neurons. Together, these observations suggest that PirB is required to regulate the functional excitatory synaptic inputs of the neuron, and that the loss of PirB just from the isolated cell examined is sufficient to account for changes in the density of both functional synapses and spines observed in $\mathrm{PirB}^{-/-}$mice.

It should be noted that the $59 \%$ increase in mEPSC frequency observed in $\mathrm{GFP}^{+} ; \mathrm{Cre}^{+}$neurons in $\mathrm{PirB}^{\mathrm{ff} / \mathrm{fl}}$ mice (Fig. $4 G, H$ ) is similar to the average $69 \%$ increase in spine density on both apical and basal dendrites (Fig. 2G-J), implying that many, if not all, of the supernumerary dendritic spines represent sites of functional excitatory synapses.
mEPSC frequency is not altered in wild-type neighbors located within $100 \mu \mathrm{m}$ of L2/3 pyramidal neurons lacking PirB

To test further for a cell-intrinsic effect of PirB on the density of functional synaptic inputs, patch-clamp recordings were made from $\mathrm{GFP}^{+} ; \mathrm{Cre}^{+}$and $\mathrm{GFP}^{-} ; \mathrm{Cre}^{-} \mathrm{L} 2 / 3$ pyramidal neurons that were in close proximity, separated by $\leq 100 \mu \mathrm{m}$ from each other (Fig. 5). Within this distance, neurons are known to have a much higher connection probability (Perin et al., 2011; Hill et al., 2012; Jouhanneau et al., 2015). In recordings from pairs of neurons located $\leq 100 \mu \mathrm{m}$ from each other (Fig. $5 A-D$ ), we found that mEPSC frequencies in $\mathrm{GFP}^{+}$; $\mathrm{Cre}^{+}$neurons were almost always greater than those for the unlabeled $\mathrm{GFP}^{-} ; \mathrm{Cre}^{-}$ neighbor (14 of 16 pairs; Fig. $5 E, G$ ). Once again, mEPSC amplitudes between $\mathrm{GFP}^{+} ; \mathrm{Cre}^{+}$and $\mathrm{GFP}^{-} ; \mathrm{Cre}^{-}$neighbors did not differ significantly (Fig. $5 F, H$ ). The average mEPSC frequency of GFP $^{+}$; Cre $^{+}$neurons (Fig. $5 E$ ) was similar to that previously recorded from $\mathrm{L} 2 / 3$ pyramidal neurons in germline PirB ${ }^{-1-}$ mice (Djurisic et al., 2013). The mEPSC frequencies of neighboring $\mathrm{GFP}^{-} ; \mathrm{Cre}^{-}$neurons (Fig. $5 E$ ) were close to previously reported levels in $\mathrm{PirB}^{+/+}$slices (Djurisic et al., 2013).

\section{Bouton density of axons arising from L2/3 neurons lacking PirB and arborizing in L5 is unaltered}

Results from experiments described above imply that PirB acting within a single L2/3 neuron can regulate the spine density of that individual neuron. To test whether 

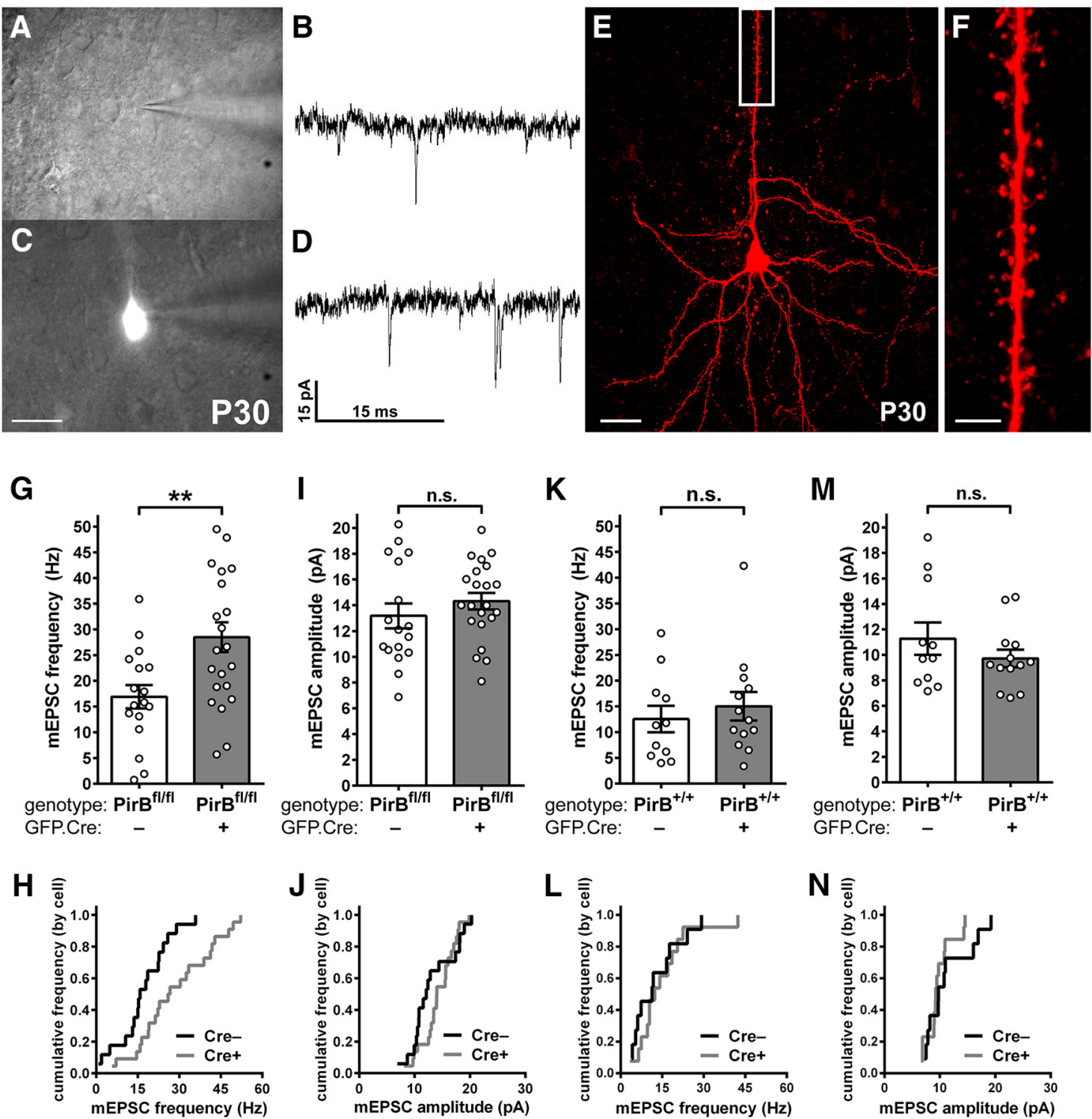

Figure 4. Sparse excision of PirB from PirB $^{\mathrm{fl} / \mathrm{fl}}$ at $\mathrm{E} 15.5$ increases mEPSC frequency but not amplitude in L2/3 pyramidal neurons in P30 visual cortex. $\boldsymbol{A}, \boldsymbol{C}$, Combined differential interference contrast and fluorescence micrographs of neurons in visual cortex used for whole-cell recordings of mEPSCs, showing GFP ${ }^{-}$; $\mathrm{Cre}^{-}$cells $(\boldsymbol{A})$ and an isolated $\mathrm{GFP}^{+} ; \mathrm{Cre}^{+}$cell $(\boldsymbol{C})$. $\boldsymbol{B}, \boldsymbol{D}$, Example $\mathrm{mEPSC}$ traces from $\mathrm{GFP}^{-} ; \mathrm{Cre}^{-}(\boldsymbol{B})$ or $\mathrm{GFP}^{+} ; \mathrm{Cre}^{+}(\boldsymbol{D}) \mathrm{L} 2 / 3$ pyramidal neurons from primary visual cortex slices of P30 PirB ${ }^{\text {fl/fl }}$ mice. $\boldsymbol{E}$, Fluorescent micrograph showing an L2/3 pyramidal neuron filled with biocytin during mEPSC recording, and visualized with Texas Redconjugated avidin. $\boldsymbol{F}$, Zoomed-in, maximum-intensity projection of the boxed area in $\boldsymbol{E}$, showing apical dendritic spines. $\boldsymbol{G}$, In PirB ${ }^{\mathrm{f} / \mathrm{fl}}$ mice, mEPSC frequency is increased in $\mathrm{GFP}^{+} ; \mathrm{Cre}^{+}$cells compared with $\mathrm{GFP}^{-}$; Cre $^{-}$cells $\left(\mathrm{GFP}^{-} ; \mathrm{Cre}^{-}: 16.91 \pm 2.28 \mathrm{~Hz}, n=17 \mathrm{cells}\right.$, 14 slices, 8 mice; GFP $^{+} ;$Cre $^{+}: 28.51 \pm 2.89 \mathrm{~Hz}, n=22$ cells, 14 slices, 8 mice; $p=0.0058^{\text {h }}$, Mann-Whitney test). $\boldsymbol{H}$, Cumulative histogram (by cell) of data presented in G. I, mEPSC amplitude does not differ between GFP ${ }^{-}$; Cre $^{-}$and GFP GFe $^{+}$cells in PirB $^{\mathrm{fl} / \mathrm{fl}}$ mice (GFP ${ }^{-}$;Cre ${ }^{-}: 13.18 \pm 0.97 \mathrm{pA}, n=17$, cells, 14 slices, 8 mice; GFP ${ }^{+}$;Cre ${ }^{+}: 14.32 \pm 0.64$ pA, $n=22$ cells, 14 slices, 8 mice; $p=0.3286^{i}$, Mann-Whitney test). $\boldsymbol{J}$, Cumulative histogram (by cell) of data presented in $\boldsymbol{I}$. $\boldsymbol{K}$, In control PirB ${ }^{+/+}$mice, electroporation of GFP.Cre did not result in an increase in mEPSC frequency in $\mathrm{GFP}^{+}$;Cre ${ }^{+}$relative to $\mathrm{GFP}^{-}$; $\mathrm{Cre}^{-}$, as expected $\left(\mathrm{GFP}^{-}\right.$;Cre ${ }^{-}: 12.53$ $\pm 2.55 \mathrm{~Hz}, n=11$ cells, 11 slices, 6 mice; GFP ${ }^{+} ; \mathrm{Cre}^{+}: 15.01 \pm 2.76, n=13$ cells, 11 slices, 6 mice; $p=0.4940^{j}$, Mann-Whitney test). $\boldsymbol{L}$, Cumulative histogram of data presented in $\boldsymbol{K} . \boldsymbol{M}$, In control PirB ${ }^{+/+}$mice, mEPSC amplitudes are not different between GFP ${ }^{+}$;Cre ${ }^{+}$ and GFP $^{-}$;Cre ${ }^{-}$cells $\left(\right.$GFP $^{-}$;Cre ${ }^{-}: 11.28 \pm 1.26 \mathrm{pA}, n=11$ cells, 11 slices, 6 mice; GFP $^{+} ;$Cre $^{+}: 9.73 \pm 0.69, n=13$ cells, 11 slices, 6 mice; $p=0.3918^{\mathrm{k}}$, Mann-Whitney test). $\boldsymbol{N}$, Cumulative histogram of data (by cell) presented in $\boldsymbol{M}$. Scale bars: $\boldsymbol{A}, \boldsymbol{C}, 25 \mu \mathrm{m} ; \boldsymbol{E}, 20$ $\mu \mathrm{m} ; \boldsymbol{F}, 5 \mu \mathrm{m} . * * p<0.01$

PirB can regulate axonal bouton density, we also analyzed at P30 the axon collaterals of L2/3 neurons that descend to cortical L5 in visual cortex (Fig. 6A,B). Note that this analysis was performed in sections from brains perfused with fixative at P30 following in utero electroporation at E15.5, similar to the methods used in Figures 1-3. The varicosities shown at high magnification in Figure $6 B$ are typical of en passant synaptic boutons. 

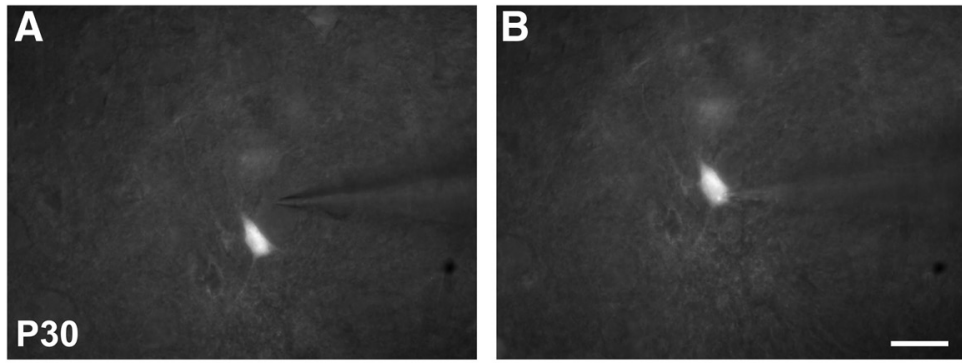

C

D

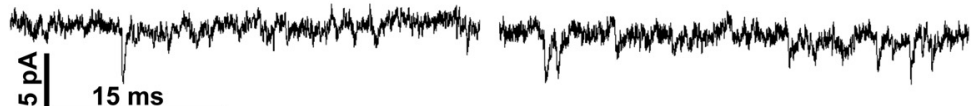

E

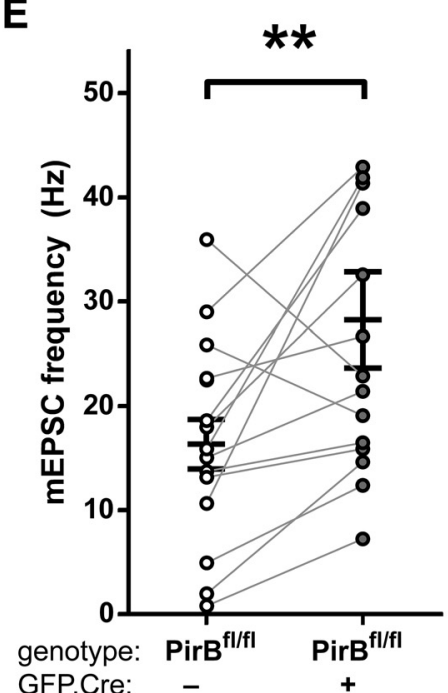

F

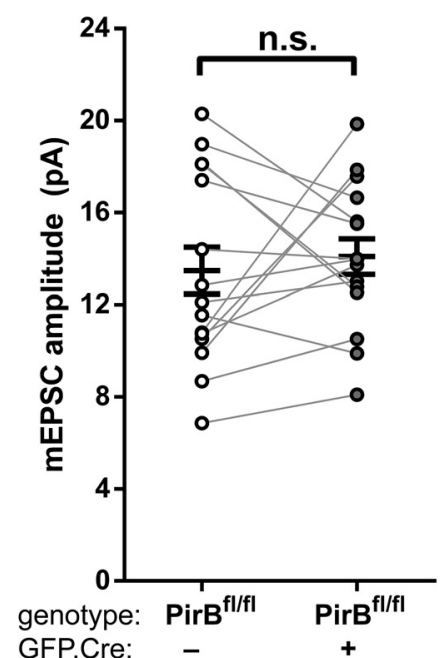

G

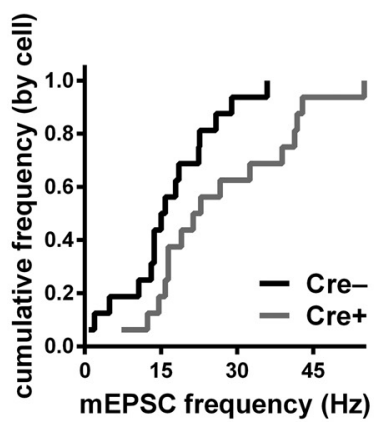

H

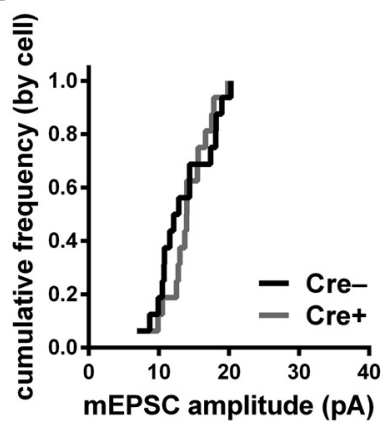

Figure 5. Sparse excision of PirB at E15.5 increases the mEPSC frequency of targeted L2/3 pyramidal neurons in visual cortex, but not in unmanipulated neighboring cells. $\boldsymbol{A}, \boldsymbol{B}$, Combined differential interference contrast and fluorescence micrograph of visual cortical slice used for whole-cell recordings, showing electrode targeting of a $\mathrm{GFP}^{-} ; \mathrm{Cre}^{-}$cell $(\boldsymbol{A})$ or an isolated $\mathrm{GFP}^{+} ; \mathrm{Cre}^{+}$cell $(\boldsymbol{B})$. $\boldsymbol{C}, \boldsymbol{D}$, Example traces of mEPSC events in $\mathrm{GFP}^{-} ; \mathrm{Cre}^{-}(\boldsymbol{C})$ or $\mathrm{GFP}^{+} ; \mathrm{Cre}^{+}(\boldsymbol{D}) \mathrm{L} 2 / 3$ pyramidal neurons in slices of visual cortex from P30 Pir ${ }^{\mathrm{fl} / \mathrm{fl}}$ mice. $\boldsymbol{E}$, In $\mathrm{PirB}^{\mathrm{fl} / \mathrm{fl}}$ mice, $\mathrm{GFP}^{+} ; \mathrm{Cre}^{+}$cells have higher mEPSC frequency compared with $\mathrm{GFP}^{-} ; \mathrm{Cre}^{-}$cells $\mathrm{GFP}^{-} ; \mathrm{Cre}^{-}$: $16.36 \pm 2.38 \mathrm{~Hz}, n=16$ cells, 10 slices, 7 mice; GFP ${ }^{+} ; \mathrm{Cre}^{+}: 28.26 \pm 4.60, n=16$ cells, 10 slices, 7 mice; $p=0.0060^{\prime}$, Wilcoxon signed-rank test). $\boldsymbol{F}$, mEPSC amplitude is not significantly different in $\mathrm{GFP}^{-} ; \mathrm{Cre}^{-}$vs $\mathrm{GFP}^{+} ; \mathrm{Cre}^{+}$cells $\left(\mathrm{GFP}^{-} ; \mathrm{Cre}^{-}: 13.49 \pm 1.01 \mathrm{pA}\right.$, $n=16$ cells, 10 slices, 7 mice; GFP $;$ Cre $^{+}: 14.10 \pm 0.77, n=16$ cells, 10 slices, 7 mice; $p=0.7722^{\mathrm{m}}$, Wilcoxon signed-rank test).

$\boldsymbol{G}, \boldsymbol{H}$, Cumulative histograms (by cell) of data presented in $\boldsymbol{E}$ and $\boldsymbol{F}$, respectively. Scale bars: $\boldsymbol{A}, \boldsymbol{B}, 25 \mu \mathrm{m} . * * p<0.01$

Bouton density of L2/3 pyramidal cell axons within L5 is not altered in GFP-labeled neurons in germline $\mathrm{PirB}^{-1-}$ mice compared with $\mathrm{PirB}^{+/+}$mice (Fig. 6C,D). Furthermore, no change in bouton density was observed in axons of isolated $\mathrm{GFP}^{+} ; \mathrm{Cre}^{+} \mathrm{L} 2 / 3$ neurons in sparsely electroporated PirB $\mathrm{fl}^{\mathrm{fl} / \mathrm{Pl}}$ mice (Fig. 6C,D). Recall that these single axons arising from neurons lacking PirB arborize in a "sea" of wild-type neurons and glia. Thus, this observa- 


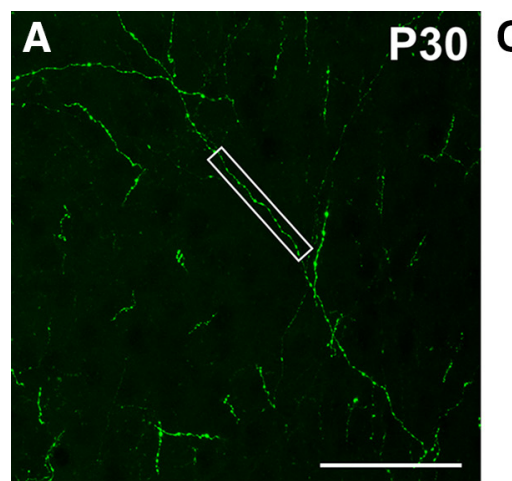

B
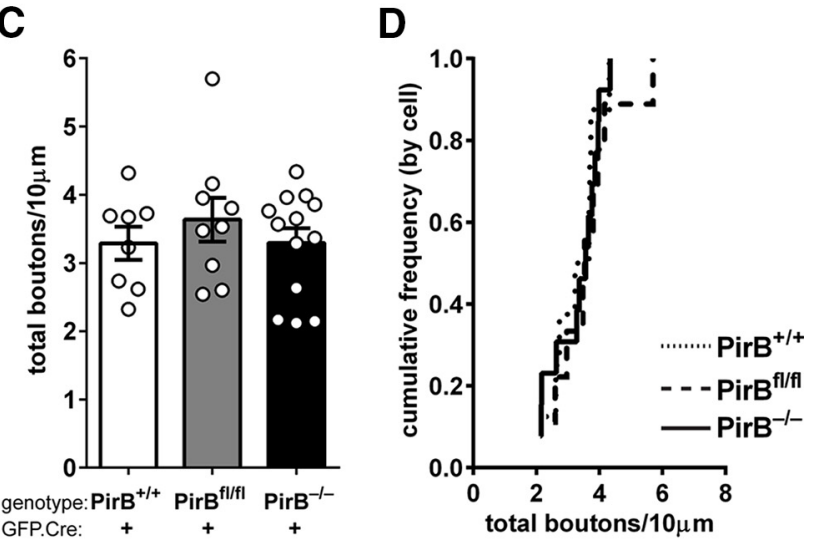

Figure 6. Bouton density on intracortical axons of $L 2 / 3$ pyramidal cells is not changed with either sparse or germline deletion of PirB. $\boldsymbol{A}$, Example fluorescence micrograph of boutons along axons within layer 5 arising from L2/3 pyramidal neurons. $\boldsymbol{B}$, Highmagnification, maximum-intensity projection of boxed area in $\boldsymbol{A}$. $\boldsymbol{C}$, Bouton density is not different among $\mathrm{PirB}^{+/+}, \mathrm{PirB}^{\mathrm{fl} / \mathrm{fl}}$, and

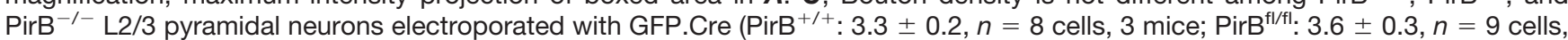

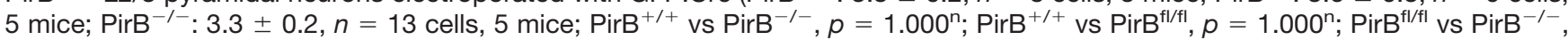
$p=1.000^{\text {n; }}$; one-way ANOVA with post hoc Bonferroni's multiple comparisons test). $\boldsymbol{D}$, Cumulative histogram of data (by cell). Scale bars: $\boldsymbol{A}, 50 \mu \mathrm{m} ; \boldsymbol{B}, 5 \mu \mathrm{m}$.

tion further supports the idea that PirB acts in a cellintrinsic manner to regulate dendritic spine density in layer $2 / 3$ pyramidal cells, leaving other aspects of neuronal structure intact, including axon bouton density and dendritic branching pattern.

\section{Discussion}

Many factors are now known to regulate aspects of dendritic spine shape, size, and stability, including experience, learning, and environmental enrichment (Holtmaat and Svoboda, 2009; Chen et al., 2014), but just how these external activity-dependent signals are read out into lasting changes is still relatively unclear. Here we have shown that PirB, a receptor whose MHC class I ligands are regulated by neural activity (Corriveau et al., 1998; Huh et al., 2000), acts within individual L2/3 pyramidal neurons in a cell-intrinsic manner to regulate spine density and functional excitatory synapses. We have used the powerful technique of in utero electroporation of Cre.GFP to target PirB deletion selectively to $L 2 / 3$ pyramidal neurons. It is remarkable that simply driving PirB excision in single isolated neurons surrounded by wild-type glia and wild-type neurons results in a major increase in spine density within the targeted neuron. This observation indicates that PirB function in individual L2/3 pyramidal neurons is required to regulate spine density. It is also consistent with the previous finding that spine density on L5 pyramidal cells is also elevated in mice lacking PirB (Djurisic et al., 2013). Together, these observations imply that PirB may regulate spine density more generally in excitatory neurons of the forebrain.

At $\mathrm{P} 30$, spine density on L2/3 pyramidal neurons lacking $\mathrm{PirB}$ is $>50 \%$ greater than in $\mathrm{PirB}^{+/+}$neurons (Figs. 1, 2). However, just 1 week earlier, at P23, we found that spine density across all genotypes exposed to GFP.Cre at $\mathrm{E} 15.5$ is similar, $\sim 13$ spines $/ 10 \mu \mathrm{m}$ (Fig. 3). Between P23 and $\mathrm{P} 30$, spine density on $\mathrm{L} 2 / 3 \mathrm{PirB}^{+/+}$neurons falls to about seven spines $/ 10 \mu \mathrm{m}$, which is consistent with the idea that this is a peak period for spine and synapse pruning (Ruiz-Marcos and Valverde, 1969; Markus and Petit, 1987). In contrast, spine density on neurons lacking PirB fails to decline and instead remains close to the level at P23. Overall, results strongly suggest that PirB function is required for spine pruning during this period. Given the strong evidence of a role for microglia in spine and synapse pruning (Schafer et al., 2012; Parkhurst et al., 2013), our results also imply that, without neuronal PirB expression, glia may not be able to function properly to eliminate spines.

Several lines of evidence presented here argue that the striking increases in spine density and functional synapses are not artifacts of Cre recombinase or GFP expression. First, a significant increase in spine density is observed when Cre.GFP is electroporated into $\mathrm{PirB}^{-1-}$ mice (Fig. 1E-J). Second, a similar result is obtained when Cre.GFP is electroporated into PirB ${ }^{\mathrm{f} / \mathrm{fl}}$ mice (Fig. $2 D-J$ ). Third, the independent technique of mEPSC recordings revealed a parallel increase in functional excitatory inputs (Figs. 4, 5), as signaled by the significantly greater mEPSC frequency in $\mathrm{PirB}^{-/-}$versus $\mathrm{PirB}^{+/+}$neurons. Moreover, whole-cell recordings of mEPSCs made from isolated neurons electroporated with Cre.GFP (Figs. 4, 5) are indistinguishable from those recorded in germline $\mathrm{PirB}^{-1-}$ neurons (Djurisic et al., 2013). Finally, when Cre.GFP is electroporated into $\mathrm{PirB}^{+/+}$mice, mEPSCs recorded from L2/3 neurons (Fig. $4 K-N$ ) are similar to those seen in unmanipulated $\mathrm{PirB}^{+/+}$mice not undergoing electroporation (Djurisic et al., 2013).

Here we have uncovered a cell-intrinsic mechanism for maintaining spine density and excitatory synaptic input below an upper bound. L2/3 neurons lacking PirB have as much as a $73 \%$ greater spine density than $\mathrm{PirB}^{+/+}$neurons (Figs. 1, 2). The corresponding increase in mEPSC frequency (Fig. 4) suggests that many of the spines on 
isolated $\mathrm{PirB}^{-1-}$ cells are functional, a finding similar to what has been observed on the L5 pyramidal neurons in $\mathrm{PirB}^{-1-}$ mice (Djurisic et al., 2013). Moreover, we observed that neurons with intact PirB alleles have lower mEPSC frequencies than their isolated neighbors lacking PirB (Fig. 5). This observation is one of the strongest arguments for a cell-autonomous role for PirB in L2/3 pyramidal neurons. The fact that mEPSC frequency in wild-type neighbors is indistinguishable from that recorded in $\mathrm{L} 2 / 3 \mathrm{PirB}^{+/+}$mice, and that mEPSC frequency in isolated $\mathrm{PirB}^{-1-}$ cells is indistinguishable from that recorded in $\mathrm{L} 2 / 3$ neurons in $\mathrm{PirB}^{-1-}$ mice, is additional support for this conclusion.

The term "cell autonomous" is used here explicitly in reference to a role for PirB in regulating spine density on L2/3 pyramidal neurons. There are several other examples in which spine density is thought to be regulated by cell-autonomous mechanisms, including NgR1 in the cortex (Akbik et al., 2013) and Sema5A in the hippocampus (Duan et al., 2014). In all of these cases, including PirB, the conclusion regarding cell-autonomous function could not have been achieved without mosaic analysis in vivo or in vitro. PirB may also have non-cell-autonomous functions. For example, the increase in mEPSC frequency recorded in isolated neurons lacking PirB implies that there has been a parallel increase in the number of presynaptic boutons, which likely derive from a vast majority of $\mathrm{PirB}^{+/+}$neurons. Thus, the spine density increase appears to drive a transynaptic increase in functional inputs: a non-cell-autonomous effect. This interpretation is also consistent with the finding here that in the sparse electroporation experiments, the axon bouton density of neurons lacking PirB does not differ from that of $\mathrm{PirB}^{+/+}$ neurons (Fig. 6). These mutant axons are embedded in a sea of PirB ${ }^{+/+}$neurons possessing normal spine density. A non-cell-autonomous role for PirB in regulating presynaptic boutons would predict that the density of axonal inputs belonging to $\mathrm{PirB}^{-1-}$ neurons should be wild type, exactly what we have observed.

There is a growing list of molecules known to regulate spines and excitatory synaptic inputs to cerebral cortical pyramidal cells. For instance, FMRP regulates spine density and maturation; in the knockout, spine density is increased, but spines remain thin and immature, and can be rescued by reducing mGluR5 expression (Dölen et al., 2007). Another receptor, DR6, regulates the density of axonal boutons and sprouting following activity-dependent deprivation, but there is no known effect on the normal developmental spine-pruning process (Marik et al., 2013). NgR1 is thought to regulate the density of mature dendritic spines (Karlsson et al., 2016); however, there is currently some disagreement about its exact role in dendritic spine and axonal bouton turnover (Akbik et al., 2013; Park et al., 2014; Frantz et al., 2016). Many downstream effectors have been identified and studied, including Rho GTPases (Murakoshi et al., 2011; Colgan and Yasuda, 2014) and the actin cytoskeleton (Kim et al., 2013; Kellner et al., 2016). In contrast, our studies suggest that PirB acts to keep spine density below a ceiling level (Djurisic et al. 2013), with no apparent effect either on the distribution of spine types (Bochner et al., 2014) or on the overall dendritic morphology (Figs. $1 K, L, 2 K, L$ ). Spine motility on L5 pyramidal neurons lacking PirB is also decreased (Djurisic et al., 2013), implying a connection between PirB and downstream signaling to cofilin and the actin cytoskeleton (Kim et al., 2013). Clearly, every aspect of the spine is tightly regulated to enable experiencedependent changes to be encoded structurally. Together, the results of our studies suggest that PirB is needed to match spine density and excitatory synaptic function to activity levels within cortical circuits, thereby providing headroom for the cell to encode additional experiences at new synapses.

\section{References}

Adelson JD, Barreto GE, Xu L, Kim T, Brott BK, Ouyang YB, Naserke T, Djurisic M, Xiong X, Shatz CJ, Giffard RG (2012) Neuroprotection from stroke in the absence of $\mathrm{MHCl}$ or PirB. Neuron 73:11001107. CrossRef Medline

Adelson JD, Sapp RW, Brott BK, Lee H, Miyamichi K, Luo L, Cheng S, Djurisic M, Shatz CJ (2016) Developmental sculpting of intracortical circuits by $\mathrm{MHC}$ class I H2-Db and H2-Kb. Cereb Cortex 26:1453-1463. CrossRef Medline

Akbik FV, Bhagat SM, Patel PR, Cafferty WB, Strittmatter SM (2013) Anatomical plasticity of adult brain is titrated by Nogo receptor 1 . Neuron 77:859-866. CrossRef Medline

Anderson SA, Eisenstat DD, Shi L, Rubenstein JL (1997) Interneuron migration from basal forebrain to neocortex: dependence on Dlx genes. Science 278:474-476. Medline

Andreu-Agullo C, Maurin T, Thompson CB, Lai EC (2011) Ars2 maintains neural stem-cell identity through direct transcriptional activation of Sox2. Nature 481:195-198. CrossRef Medline

Arellano JI, Benavides-Piccione R, Defelipe J, Yuste R (2007) Ultrastructure of dendritic spines: correlation between synaptic and spine morphologies. Front Neurosci 1:131-143. CrossRef Medline

Bochner DN, Sapp RW, Adelson JD, Zhang S, Lee H, Djurisic M, Syken J, Dan Y, Shatz CJ (2014) Blocking PirB up-regulates spines and functional synapses to unlock visual cortical plasticity and facilitate recovery from amblyopia. Sci Transl Med 6:258ra140. CrossRef Medline

Bukhari N, Burman PN, Hussein A, Demars MP, Sadahiro M, Brady DM, Tsirka SE, Russo SJ, Morishita H (2015) Unmasking proteolytic activity for adult visual cortex plasticity by the removal of Lynx1. J Neurosci 35:12693-12702. CrossRef Medline

Chen B, Wang SS, Hattox AM, Rayburn H, Nelson SB, McConnell SK (2008) The Fezf2-Ctip2 genetic pathway regulates the fate choice of subcortical projection neurons in the developing cerebral cortex. Proc Natl Acad Sci U S A 105:11382-11387. CrossRef Medline

Chen CC, Lu J, Zuo Y (2014) Spatiotemporal dynamics of dendritic spines in the living brain. Front Neuroanat 8:28. CrossRef Medline

Colgan LA, Yasuda R (2014) Plasticity of dendritic spines: subcompartmentalization of signaling. Annu Rev Physiol 76:365-385. CrossRef Medline

Corriveau RA, Huh GS, Shatz CJ (1998) Regulation of class I MHC gene expression in the developing and mature CNS by neural activity. Neuron 21:505-520. Medline

Crozier RA, Wang Y, Liu CH, Bear MF (2007) Deprivation-induced synaptic depression by distinct mechanisms in different layers of mouse visual cortex. Proc Natl Acad Sci U S A 104:1383-1388. CrossRef Medline

De Paola V, Holtmaat A, Knott G, Song S, Wilbrecht L, Caroni P, Svoboda K (2006) Cell type-specific structural plasticity of axonal branches and boutons in the adult neocortex. Neuron 49:861-875. CrossRef Medline

Djurisic M, Vidal GS, Mann M, Aharon A, Kim T, Ferrao Santos A, Zuo Y, Hübener M, Shatz CJ (2013) PirB regulates a structural sub- 
strate for cortical plasticity. Proc Natl Acad Sci U S A 110:2077120776. CrossRef Medline

Dölen G, Osterweil E, Rao BS, Smith GB, Auerbach BD, Chattarji S, Bear MF (2007) Correction of fragile $X$ syndrome in mice. Neuron 56:955-962. CrossRef Medline

Duan Y, Wang SH, Song J, Mironova Y, Ming GL, Kolodkin AL, Giger RJ (2014) Semaphorin 5A inhibits synaptogenesis in early postnatal- and adult-born hippocampal dentate granule cells. eLife 3:e04390. CrossRef Medline

Faul F, Erdfelder E, Lang A-G, Buchner A (2007) G*Power 3: a flexible statistical power analysis program for the social, behavioral, and biomedical sciences. Behav Res Methods 39:175-191. Medline

Faul F, Erdfelder E, Buchner A, Lang A-G (2009) Statistical power analyses using G*Power 3.1: tests for correlation and regression analyses. Behav Res Methods 41:1149-1160. CrossRef Medline

Frantz MG, Kast RJ, Dorton HM, Chapman KS, McGee AW (2016) Nogo receptor 1 limits ocular dominance plasticity but not turnover of axonal boutons in a model of amblyopia. Cereb Cortex 26:19751985. CrossRef Medline

Fu M, Yu X, Lu J, Zuo Y (2012) Repetitive motor learning induces coordinated formation of clustered dendritic spines in vivo. Nature 483:92-95. CrossRef Medline

Gordon JA, Stryker MP (1996) Experience-dependent plasticity of binocular responses in the primary visual cortex of the mouse. $J$ Neurosci 16:3274-3286. Medline

Greig LC, Woodworth MB, Galazo MJ, Padmanabhan H, Macklis JD (2013) Molecular logic of neocortical projection neuron specification, development and diversity. Nat Rev Neurosci 14:755-769. CrossRef Medline

Hayashi-Takagi A, Yagishita S, Nakamura M, Shirai F, Wu YI, Loshbaugh AL, Kuhlman B, Hahn KM, Kasai H (2015) Labelling and optical erasure of synaptic memory traces in the motor cortex. Nature 525:333-338. CrossRef Medline

Hill SL, Wang Y, Riachi I, Schürmann F, Markram H (2012) Statistical connectivity provides a sufficient foundation for specific functional connectivity in neocortical neural microcircuits. Proc Natl Acad Sci U S A 109:E2885-E2894. CrossRef

Hippenmeyer S, Youn YH, Moon HM, Miyamichi K, Zong H, Wynshaw-Boris A, Luo L (2010) Genetic mosaic dissection of Lis1 and Ndel1 in neuronal migration. Neuron 68:695-709. CrossRef Medline

Hofer SB, Mrsic-Flogel TD, Bonhoeffer T, Hübener M (2006) Prior experience enhances plasticity in adult visual cortex. Nat Neurosci 9:127-132. CrossRef Medline

Hofer SB, Mrsic-Flogel TD, Bonhoeffer T, Hübener M (2009) Experience leaves a lasting structural trace in cortical circuits. Nature 457:313-318. CrossRef Medline

Holtmaat A, Svoboda K (2009) Experience-dependent structural synaptic plasticity in the mammalian brain. Nat Rev Neurosci 10:647658. CrossRef Medline

Huh GS, Boulanger LM, Du H, Riquelme PA, Brotz TM, Shatz CJ (2000) Functional requirement for class I MHC in CNS development and plasticity. Science 290:2155-2159. Medline

Jouhanneau JS, Kremkow J, Dorrn AL, Poulet JF (2015) In vivo monosynaptic excitatory transmission between layer 2 cortical pyramidal neurons. Cell Rep 13:2098-2106. CrossRef Medline

Karlsson TE, Smedfors G, Brodin AT, Åberg E, Mattsson A, Högbeck I, Wellfelt K, Josephson A, Brené S, Olson L (2016) NgR1: a tunable sensor regulating memory formation, synaptic, and dendritic plasticity. Cereb Cortex 26:1804-1817. CrossRef Medline

Kellner Y, Fricke S, Kramer S, lobbi C, Wierenga CJ, Schwab ME, Korte M, Zagrebelsky M (2016) Nogo-A controls structural plasticity at dendritic spines by rapidly modulating actin dynamics. Hippocampus 26:816-831.

Kim T, Vidal GS, Djurisic M, William CM, Birnbaum ME, Garcia KC, Hyman BT, Shatz CJ (2013) Human LilrB2 is a $\beta$-amyloid receptor and its murine homolog PirB regulates synaptic plasticity in an Alzheimer's model. Science 341:1399-1404. CrossRef
Lu W, Bushong EA, Shih TP, Ellisman MH, Nicoll RA (2013) The cell-autonomous role of excitatory synaptic transmission in the regulation of neuronal structure and function. Neuron 78:433-439. CrossRef Medline

Ma L, Qiao Q, Tsai JW, Yang G, Li W, Gan WB (2016) Experiencedependent plasticity of dendritic spines of layer $2 / 3$ pyramidal neurons in the mouse cortex. Dev Neurobiol 76:277-286. CrossRef Medline

Marik SA, Olsen O, Tessier-Lavigne M, Gilbert CD (2013) Death receptor 6 regulates adult experience-dependent cortical plasticity. J Neurosci 33:14998-15003. CrossRef Medline

Markus EJ, Petit TL (1987) Neocortical synaptogenesis, aging, and behavior: lifespan development in the motor-sensory system of the rat. Exp Neurol 96:262-278. Medline

McConnell SK, Kaznowski CE (1991) Cell cycle dependence of laminar determination in developing neocortex. Science 254:282285. Medline

McGee AW, Yang Y, Fischer QS, Daw NW, Strittmatter SM (2005) Experience-driven plasticity of visual cortex limited by myelin and Nogo receptor. Science 309:2222CrossRef Medline

Morishita H, Miwa JM, Heintz N, Hensch TK (2010) Lynx1, a cholinergic brake, limits plasticity in adult visual cortex. Science 330: 1238. CrossRef Medline

Muhia M, Willadt S, Yee BK, Feldon J, Paterna JC, Schwendener S, Vogt K, Kennedy MB, Knuesel I (2012) Molecular and behavioral changes associated with adult hippocampus-specific SynGAP1 knockout. Learn Mem 19:268-281. CrossRef

Murakoshi H, Wang H, Yasuda R (2011) Local, persistent activation of Rho GTPases during plasticity of single dendritic spines. Nature 472:100-104. CrossRef Medline

Nery S, Fishell G, Corbin JG (2002) The caudal ganglionic eminence is a source of distinct cortical and subcortical cell populations. Nat Neurosci 5:1279-1287. CrossRef Medline

Park JI, Frantz MG, Kast RJ, Chapman KS, Dorton HM, Stephany CÉ, Arnett MT, Herman DH, McGee AW (2014) Nogo receptor 1 limits tactile task performance independent of basal anatomical plasticity. PLoS One 9:e112678CrossRef Medline

Parkhurst CN, Yang G, Ninan I, Savas JN, Yates JR 3rd, Lafaille JJ, Hempstead BL, Littman DR, Gan WB (2013) Microglia promote learning-dependent synapse formation through brain-derived neurotrophic factor. Cell 155:1596-1609. CrossRef Medline

Paxinos G, Franklin KBJ (2008). The mouse brain in stereotaxic coordinates, Ed 3. New York: Academic.

Perin R, Berger TK, Markram H (2011) A synaptic organizing principle for cortical neuronal groups. Proc Natl Acad Sci U S A 108:54195424. CrossRef Medline

Pizzorusso T, Medini P, Berardi N, Chierzi S, Fawcett JW, Maffei L (2002) Reactivation of ocular dominance plasticity in the adult visual cortex. Science 298:1248-1251. CrossRef Medline

Qin JY, Zhang L, Clift KL, Hulur I, Xiang AP, Ren B-Z, Lahn BT (2010) Systematic comparison of constitutive promoters and the doxycycline-inducible promoter. PLoS One 5:e10611. CrossRef Medline

Ruiz-Marcos A, Valverde F (1969) The temporal evolution of the distribution of dendritic spines in the visual cortex of normal and dark raised mice. Exp Brain Res 8:284-294. Medline

Saito T (2006) In vivo electroporation in the embryonic mouse central nervous system. Nat Protoc 1:1552-1558. CrossRef Medline

Saito T, Nakatsuji N (2001) Efficient gene transfer into the embryonic mouse brain using in vivo electroporation. Dev Biol 240:237-246. CrossRef Medline

Schafer DP, Lehrman EK, Kautzman AG, Koyama R, Mardinly AR, Yamasaki R, Ransohoff RM, Greenberg ME, Barres BA, Stevens B (2012) Microglia sculpt postnatal neural circuits in an activity and complement-dependent manner. Neuron 74:691-705. CrossRef

Scotto-Lomassese S, Nissant A, Mota T, Néant-Féry M, Oostra BA, Greer CA, Lledo PM, Trembleau A, Caillé I (2011) Fragile X mental 
retardation protein regulates new neuron differentiation in the adult olfactory bulb. J Neurosci 31:2205-2215. CrossRef Medline

Sholl DA (1953) Dendritic organization in the neurons of the visual and motor cortices of the cat. J Anat 87:387-406. Medline

Syken J, Grandpre T, Kanold PO, Shatz CJ (2006) PirB restricts ocular-dominance plasticity in visual cortex. Science 313:17951800. CrossRef Medline

Tabata H, Nakajima K (2001) Efficient in utero gene transfer system to the developing mouse brain using electroporation: visualization of neuronal migration in the developing cortex. Neuroscience 103: 865-872.

Xu J, Pang ZP, Shin OH, Südhof TC (2009a) Synaptotagmin-1 functions as a $\mathrm{Ca} 2+$ sensor for spontaneous release. Nat Neurosci 12:759-766. CrossRef Medline

Xu T, Yu X, Perlik AJ, Tobin WF, Zweig JA, Tennant K, Jones T, Zuo Y (2009b) Rapid formation and selective stabilization of synapses for enduring motor memories. Nature 462:915-919. CrossRef Medline 